\title{
Communication-Based Assessment for Bank Operations
}

Paul Mitchell

Karla Chaman-Ruiz

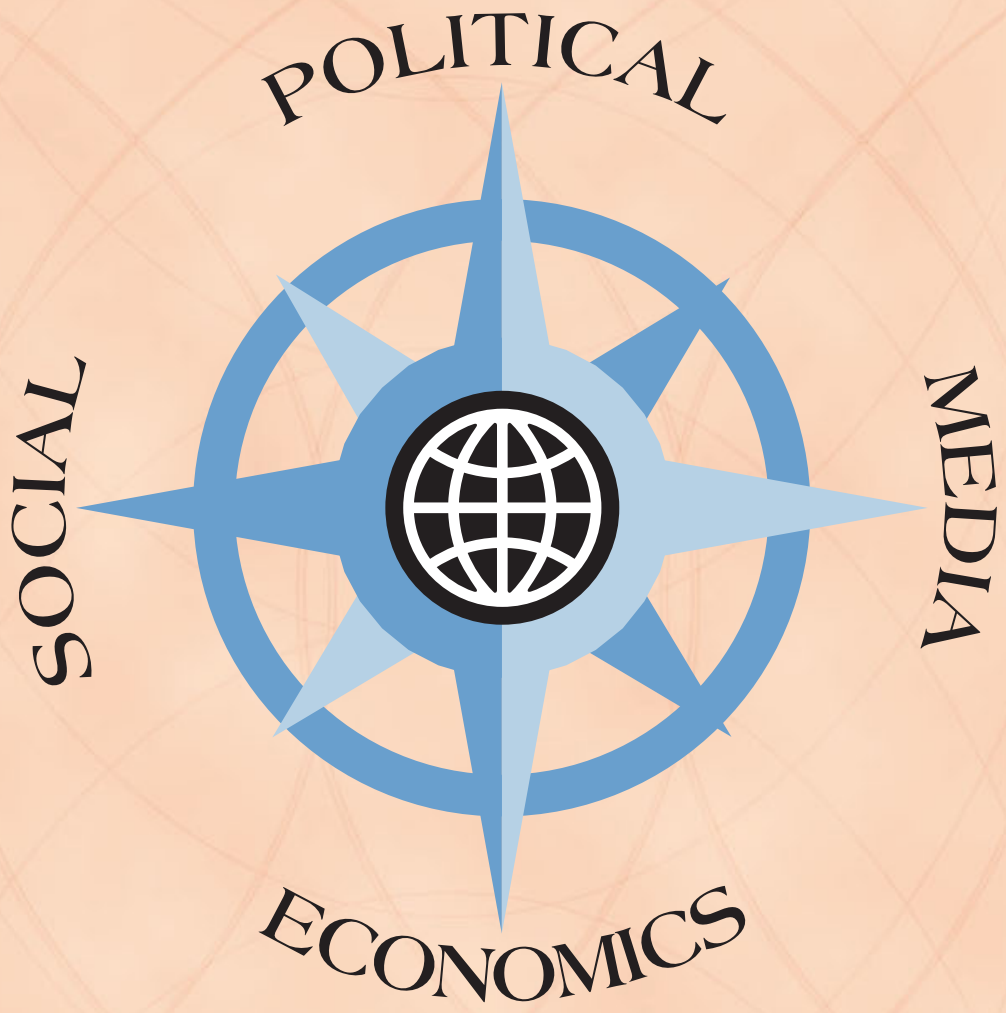





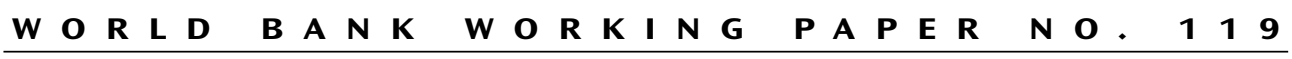

\section{Communication-Based Assessment for Bank Operations}

Paul Mitchell

Karla Chaman-Ruiz

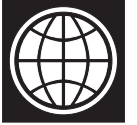

THE WORLD BANK

Washington, D.C. 
Copyright (C) 2007

The International Bank for Reconstruction and Development/The World Bank

1818 H Street, N.W.

Washington, D.C. 20433, U.S.A.

All rights reserved

Manufactured in the United States of America

First Printing: June 2007

(2)

printed on recycled paper

\section{7}

World Bank Working Papers are published to communicate the results of the Bank's work to the development community with the least possible delay. The manuscript of this paper therefore has not been prepared in accordance with the procedures appropriate to formally-edited texts. Some sources cited in this paper may be informal documents that are not readily available.

The findings, interpretations, and conclusions expressed herein are those of the author(s) and do not necessarily reflect the views of the International Bank for Reconstruction and Development/The World Bank and its affiliated organizations, or those of the Executive Directors of The World Bank or the governments they represent.

The World Bank does not guarantee the accuracy of the data included in this work. The boundaries, colors, denominations, and other information shown on any map in this work do not imply any judgment on the part of The World Bank of the legal status of any territory or the endorsement or acceptance of such boundaries.

The material in this publication is copyrighted. Copying and/or transmitting portions or all of this work without permission may be a violation of applicable law. The International Bank for Reconstruction and Development/The World Bank encourages dissemination of its work and will normally grant permission promptly to reproduce portions of the work.

For permission to photocopy or reprint any part of this work, please send a request with complete information to the Copyright Clearance Center, Inc., 222 Rosewood Drive, Danvers, MA 01923, USA, Tel: 978-750-8400, Fax: 978-750-4470, www.copyright.com.

All other queries on rights and licenses, including subsidiary rights, should be addressed to the Office of the Publisher, The World Bank, 1818 H Street NW, Washington, DC 20433, USA, Fax: 202-522-2422, email: pubrights@worldbank.org.

ISBN-10: 0-8213-7165-7

ISBN-13: 978-0-8213-7165-7

eISBN: 978-0-8213-7166-4

ISSN: $1726-5878$

DOI: $10.1596 / 978-0-8213-7165-7$

Paul Mitchell is Manager of the Development Communications division of the External Affairs department of the World Bank. Karla Chaman-Ruiz is a Communications Officer in the same division.

Library of Congress Cataloging-in-Publication Data has been requested. 


\section{Contents}

Preface $\quad$ V

Acknowledgments vii

1. Introduction 1

Development Communication for Success and Sustainability 1

Case for Strategic Communications 2

Communications-Based Assessment: The First Step 2

2. Framework 5

Research and Practice 5

$\begin{array}{ll}\text { Trust and Transparency in the Communications Relationship } & 6\end{array}$

3. The Development Communication Methodology 9

4. The Communication-Based Assessment (CBA) 11

$\begin{array}{ll}\text { Situational Knowledge } & 11\end{array}$

$\begin{array}{ll}\text { Socio-political Analysis } & 12\end{array}$

$\begin{array}{ll}\text { General Application of CBA in Reform Cases } & 13\end{array}$

$\begin{array}{ll}\text { CBA Procedur } & 14\end{array}$

5. Opening the Dialogue: Components of the

$\begin{array}{ll}\text { Communication-Based Assessment } & 17\end{array}$

$\begin{array}{ll}\text { Governmental and Political Risk Analysis } & 17\end{array}$

$\begin{array}{ll}\text { Stakeholder Analysis } & 21\end{array}$

Media, Communication Research Environment, and Local Capacity 23

$\begin{array}{ll}\text { Social and Participatory Communication } & 28\end{array}$

6. Contribution of the CBA to Operational Projects 31

Alignment of Development Objectives $\quad 31$

Identificaton of Audiences $\quad 32$

Assessment and Mitigation of Social and Political Risks 33

Identification of Stakeholders' Positions 36

Identification of "Champions" for the Initiative 36

Understanding of Decisionmaking Mechanisms 38

Inputs for a Sound Public Communication Program 40

Capacity-building for Achieving Effective Communication 42 
Ensuring Internal Coordination and Consistency 43

$\begin{array}{ll}\text { Conclusion } & 44\end{array}$

$\begin{array}{ll}\text { References } & 47\end{array}$

\section{LIST OF FIGURES}

1. Development Communication Approach $\quad 10$

2. Analytical Work of CBA 14

3. Importance of Issues (Ghana Urban Water Reform) 32

4. Most Important Aspect of Water Service (Ghana Urban Water Reform) 32

5. Major Audiences (Mauritius) 34

6. The Reality of Institutional Settings 35

7. Georgia Judicial Reform Socio-Policital Risk Analysis 35

8. Players (Ghana) 38

9. Basic Organizational Communication Chart for ALRMP II (Kenya) 39

10. Communication Action Plan Components 40

11. Main Areas of Intervention (Brazil) 41

12. Trusted Sources 41

13. Messages 43

14. Guidelines 44

\section{LIST OF BOXES}

1. Governmental and Political Analysis (Issues to be Covered by the CBA) 20

2. Stakeholder Analysis (Issues to be Covered by the CBA) 24

3. Media and Communication Research Environment Analysis

4. Social and Participatory Communication Analysis

(Issues to be Covered by the CBA) 29

5. Analysis of Critical Audiences (Water and Sanitation PSP, Mauritius) 37 


\section{Preface}

$\mathrm{T}$

he world of development and the world of communication are changing rapidly. There are new entrants to development, new ways of listening and encouraging participation, and new needs for communication. It is not only the technology of communication and its application that is changing rapidly, but also the way communication is viewed related to development. The traditional view that communication is a one-way process of information dissemination and is peripheral to the development process has been superseded by the view that communication is integral to the very design of development itself.

Communication can help in the understanding of the political, social, and cultural environments in which development is taking place. This contextual knowledge identifies these non-financial risks, ascertains how societies interact and reveals their perceptions, priorities, expectations, language codes, cultures and channels of communication. It reviews the development initiative from the perspective of those affected by the development and helps policymakers base their decisions on a clear understanding of beneficiaries' perspectives from the beginning of the development initiative. This facilitates improved project design and meaningful participation and consultation processes.

As part of the development communication methodology used by the World Bank, the Communication-based Assessment identifies the knowledge, perceptions, fears, and expectations of the stakeholders affected by the development initiative. When used at the initial stage of designing a development intervention, communication can make an integral contribution to development.

This paper provides a mix of theory backed by practice in the field and a detailed guide to undertaking a Communication-based Assessment. It is the compilation of many years of field work in applying the framework. We hope project teams find this a useful guide to incorporating communication into their work to help achieve results meaningful to the people who are meant to benefit from development initiatives. 



\section{Acknowledgments}

This work would not have been possible without the contributions of the members of 1 the Development Communication Division (DevComm) who have provided numerous materials and examples to enrich this document. In particular, the authors would like to thank Jose Manuel Bassat, Leonardo Mazzei, and Paolo Mefalopulos for their insightful contributions to this work. Thanks are owed also to Fumiko Nagano for her suggestions and constant support and Zita Lichtenberg and Barbara Catherwood for their editorial assistance. The views expressed herein are in solely those of the authors and not of any of their affiliated organizations. 



\section{Introduction}

$\mathrm{T}$

he World Bank and other development organizations work closely with governments to improve the living conditions of people in developing countries, expanding their development visions and helping them to achieve their goals. The impact of these development interventions can be measured by social and economic outcomes and by the sustainability of results across the wide range of sectors in which the work takes place (health, education, infrastructure, and so forth). Ultimately development is about change. The World Bank's experience with development initiatives shows that the transfer of knowledge alone cannot produce the behavior change necessary for success in projects and reforms. The necessary change is a complex process, one which requires strategic communication interventions.

\section{Development Communication for Success and Sustainability}

Development communication is a client-oriented strategy, contributing a powerful set of tools for the success of development initiatives. A well-designed development communication strategy based on a clear understanding of the client's perspective assists development practitioners in decisionmaking from design to evaluation. Shifting the emphasis from the point of view of the change agent to the perspective of the people directly affected by the reforms, development communication informs donors and engages stakeholders, leading to the long-term sustainability of projects and reforms.

The Development Communication Division (DevComm) of the World Bank has the responsibility and the challenge of providing technical assistance to client countries and operational staff in the strategic use of communication during the project and reform processes. DevComm assists in the selection and use of communications tools to complement 
development initiatives. The incorporation of well-conceived, professionally implemented communication programs contributes an understanding of political, social and cultural realities into the design and execution of initiatives and can make the difference between success and failure.

\section{Case for Strategic Communications}

The World Bank and other development organizations have relied on traditional information dissemination approaches to communication to achieve development goals. This "one-way" communication process has proven insufficient, consuming significant financial resources for conventional information tools, such as advertising. Information dissemination alone has not created the enduring frameworks that allow for real changes in clients' behaviors, perceptions, or attitudes.

A more effective approach frames communication as an integral "two-way" process that engages stakeholders, understands their socio-political context, and takes their perspectives into account through development process. This integrated two-way process constitutes a new communication approach, providing a better understanding of the development context, tailoring development initiatives during design and implementation, and contributing to more sustainable results by allowing project managers to better recognize and mitigate risks.

Strategic communication can be understood as the development of programs designed to achieve management objectives by influencing the voluntary behavior of key stakeholder audiences. Changing behavior is particularly critical in development programs, where simply increasing awareness about a development issue is usually inadequate to achieve the changes necessary for reform. People must have a base of knowledge and, equally important, a positive attitude about the reform and a motivation to change current practices.

Economic and financial analyses are only part of the knowledge required to propose, design, and implement a development initiative. A more comprehensive view or "situational knowledge" is necessary. This identifies the risks related to the political economy, the social relationships related to the initiative, and the culture in which the initiative is taking place. It ascertains how societies interact and reveals their perceptions, priorities, expectations, language codes, cultures, influential organizations, mechanisms of participation, community relations, and channels of communication.

Often reforms are viewed from the standpoint of the implementing agencies and not from the point of view of the people whose lives are directly affected by reform. Strategic communication techniques inform and enable policymakers to base their decisions on a clear understanding of beneficiaries' perspectives from the beginning of a development project or reform. The Communications-Based Assessment (CBA) is the initial strategic tool that can improve significantly the outcomes of development initiatives.

\section{Communications-Based Assessment: The First Step}

The development communication methodology employed by DevComm challenges World Bank staff and other practitioners to deepen their understanding of the social, political, economic, and cultural environment in which they work. The enhanced understanding 
facilitates constructive participation and improves project design and execution, while increasing the likelihood of sustainability for projects or reforms. This methodology allows for dynamic and highly contextual investigations that complement the static financial and economic analyses traditionally used.

The first stage of the methodology, the Communication-Based Assessment (CBA), helps to identify the knowledge, perceptions, fears, and expectations_-if any-of the main stakeholders. Based on this information, appropriate adjustments are made to the design of the development initiative. The CBA provides task managers and decision makers with additional tools to assess the knowledge and attitudes of stakeholders, establish a stronger rapport, and better respond to their expectations.

The CBA is most effective when applied at the earliest stage of the development initiative-in the identification or design phase of a development intervention. The communication tools identify the societal networks of communication influencing development and the political risk related to the initiatives. DevComm assists practitioners to integrate key information elements into the design and implementation of development initiatives, thereby improving understanding of the country and its stakeholders and achieving greater impact. This paper presents the methodology used by DevComm and its clients to improve development outcomes based on a Communication-Based Assessment (CBA) approach. 



\section{Framework}

I

nformation is not the same as communication. The concept of communication goes beyond the transmission of messages and encompasses a two-way exchange of perceptions, knowledge, and experiences. In the framework of development communication, information dissemination is only part of the communication process. (Windahl, Signitzer, and Olson 1992). Only recently has this broader definition of communication been adopted by the World Bank. Previously a project's communication component was often confined to "information and dissemination," producing and transferring information about the goals of a particular project through traditional media to the government, general public, and other stakeholders. This traditional information dissemination approach has proven valuable only for specific purposes and in limited circumstances.

This new approach of communication for development is starting to filter into the political consciousness. In a November 2004 speech, Hilary Benn (MP), Secretary of State for International Development in the UK, called for "not just communication that secures column inches or airtime, but communication which educates and brings about better ways of doing things; which helps government talk to its citizens and vice-versa; and which puts the poorest of the poor at the centre of attention."

\section{Research and Practice}

In a broad sense "communication support helps create the human environment necessary for a development project or program to succeed" (Perrett n.d.). Chances for success and sustainability increase when the stakeholders join the process. In the case of public sector reforms, "reformers often assume that the purpose of communication is merely to raise awareness of the reform program after the program has been formulated by technocrats 
and policy advisers" (Cabanero-Verzosa and Mitchell 2002). Awareness of governmental reforms, however, does not imply acceptance or sustainability. Researchers identify the final outcome of the communication process as a change in social behavior (CabaneroVerzosa 2000). Without social or individual change, it is not possible to achieve sustainable change in a development intervention.

The World Bank's operational work can act as a catalyst to promote change, but the change must come from the stakeholders in order to be sustainable. Promoting change involves a thorough understanding of cultural, political, and social codes, as well as knowledge of economic and financial environment.

The institutional framework is crucial for development. "One feature of good institutions and policies is that they not only facilitate the transfer of knowledge, but also enhance the likelihood that such knowledge will be used effectively" (Stiglitz 1998). In order to promote change, practitioners need to comprehend the complexity of the local and national setting: the modus operandi of government; the value that governments and stakeholders place on the proposed development model; the power of its supporters and opponents; their access to information; and the institutional capacity for achieving the goals.

Development communication serves projects and reforms across sectors and contributes to the involvement, ownership, and understanding of the range of stakeholders. Recent studies by the World Bank's Operations Evaluation Department (OED 2004) bear this out. A study from Europe and Central Asia states that, "Experience in countries such as Poland and Russia (coal restructuring) and Bulgaria (pension reform) shows that however well designed a reform, its rate of progress is largely determined by the government's ownership of it and degree of consensus it is able to mobilize in the society at large. A wellinformed civil society can become a major driver for change. Programs to generate stakeholder awareness and participation should be replicated widely."

The OED study goes on to state that "it appears an inadequate understanding of the political and social situation contributed to failures in some operations. The design and implementation of reform initiatives should be based on an understanding of the underlying political and social processes at the core of government that determine the motivation and behavior of stakeholders. Such understanding would enable the reforms to take into account the realities that help explain the functioning of public institutions. Stakeholder analysis, which until recently was largely absent from the ECA regions' work programs, should be standard practice, and an integral part of the program and project design.”

In the evaluation of Cape Verde's privatization program, OED concluded that the program's success was based on "strategic communications focused on political commitment and support for privatization; ownership building and stakeholder participation; labor retrenchment through consultation; and communication campaigns to build public support and ensure transparency." The communication process is complex and must interact with all the other components of a project to build the appropriate support for accomplishing the objectives. Achieving transparency and trust is a crucial part of this task.

\section{Trust and Transparency in the Communications Relationship}

Trust is a key factor in achieving positive development outcomes. Neither general information nor targeted messages are absorbed and shared if the recipients do not trust the 
source. The economic and human returns of trust are evident. Knack and Keefer (1997) state that trusting societies not only have stronger incentives to innovate and accumulate physical capital but also are likely to have higher returns to accumulation of human capital. In addition to its effect on economic outcome, trust also has a positive effect on the credibility, transparency, and legitimacy of a project's performance. An inclusive communication strategy incorporating feedback helps to build trust and promote transparency. The open channels of communication empower stakeholders, establish ownership, and lead to successful development outcomes.

Simply disseminating or disclosing information does not achieve transparency. Practitioners need to know the level of public trust in the governmental agencies and institutions that will implement the project or the reform. In addition, if the project language is not clear or if the political "champion" delivering the information does not have enough credibility, these efforts to connect with and persuade audiences can be useless. A development communication strategy can measure public confidence and help to clean and to clear the path for trust to grow.

Important communication-related questions should be asked during the design phase of the project to avoid problems in later phases. Is the terminology of the project or reform understood by all relevant audiences? Is the political "champion" of the project trusted by the most relevant stakeholders? Failure to look at these multiple communication dimensions often leads to a crisis requiring corrective measures. A range of different methodologies exists for the communication specialist to diagnose problems related to a project, government, and beneficiaries. If these methodologies are applied too late, however, problems acquire greater dimensions. By adopting more preventive measures, such as incorporating a development communication approach and conducting a Communication-Based Assessment at the first design stage of the process, potential risks can be diminished. 



\section{The Development Communication Methodology}

Communication support for development generally encompasses four dimensions:

Internal communication achieves internal consensus on goals and messages before going "outside." This dimension is essential whether it is applied to a policy initiative, a campaign, or a project.

Corporate communication explains what an organization is and does. It builds a base of trust, allowing the institution to engage in dialogue and to strengthen belief in its work, which in the case of the World Bank is development. Corporate communication should not simply boost the image of the organization but should also serve the goals of the stakeholders.

Advocacy communication consists of programs to raise the profile of an issue to the point where action is taken.

Operational support comprises communication programs that directly support operations through risk analysis and mitigation work.

Regardless of the complexity of the development initiative-whether it is a campaign to encourage hand washing or to build consensus on the need for economic reforms- the development communication approach implies a standard methodology with four main stages (Mefalopulos Forthcoming; see Figure 1):

1. Communication-Based Assessment: The initial stage gathers information about stakeholders' knowledge, perceptions, attitudes, expectations, and practices that can tailor the design of the development initiative. This research can identify indicators for exante evaluation, analyze the social and political risks for the development initiative, and 


\section{Figure 1. Development Communication Approach}

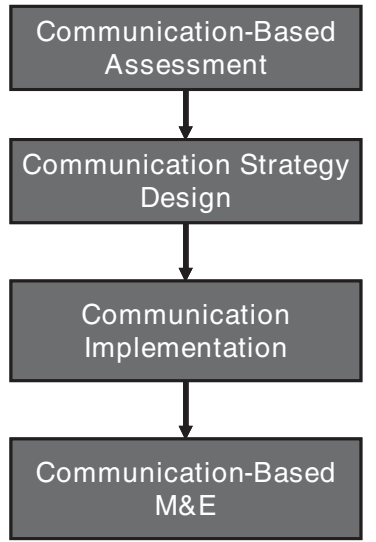

assess the capacity of the government to implement and supervise the communication strategy. At the end of the assessment, the communication objectives are identified and probed further. This stage may also identify the areas where further and deeper public opinion research, both quantitative and qualitative, is required.

2. Communication Strategy Design: Based on the assessment results, the development communication objectives are now reviewed, finalized, and adjusted to the overall goals of the development initiative. In the case of projects, the assessment research and communication objectives can improve the information/dissemination component, and they can modify and adapt the Terms of Reference for hiring a firm or a consultant. In addition, the research and objectives can highlight guidelines and activities for strengthening the government's capacity. The communication strategy should answer the following five management questions (Cabanero-Verzosa and Paul Mitchell 2002):

(a) Which audiences need to be reached by the communication component?

(b) What are the required behavior changes?

(c) What messages are more appropriate?

(d) Which channels of communication will be most effective?

(e) How will the communication process be monitored and evaluated?

3. Communication Implementation: This stage relies mainly on the capacity of the government to manage, deliver, and monitor the communication strategy. Governments can build this capacity (training on strategic communications can be carried out), buy it (hiring a local firm or consultants), or import it into the country (hiring international consultants). Supervision is required for this stage of the work. Furthermore, some indicators for the non-financial-social, cultural, institutional, and political-aspects of the project, policy, or reform to be addressed by the communication program may be developed and included in the monitoring and evaluation (M\&E) system already planned for the overall project.

4. Communication-Based M\&E: Traditional results and ex-post evaluations (based on the indicators of the ex-ante evaluation) should be developed for all communication interventions. However, given that development reforms and the corresponding communication interventions are highly contextual and that any communication intervention can change the conditions of the project, the development initiative needs to receive periodic feedback from the main stakeholders. This feedback may help redefine both the implementation of the development initiative itself and the communication program in order to better accomplish the development goals. 


\section{The Communication-Based Assessment (CBA)}

$\mathrm{T}$ The Bank and its client governments require feedback from stakeholders for successful outcomes when designing, implementing, and evaluating development initiatives. This feedback is a crucial and complex factor for development sustainability. It is based-from a communication perspective-on stakeholder participation and ownership. The traditional economic analysis carried out by World Bank staff, therefore, must be complemented with a comprehensive analysis of the social, cultural, institutional, and political context, as well as an assessment of the stakeholders involved in the development initiative. In Joseph Stiglitz's words "in development work, the focus has shifted to the intangibles of knowledge, institutions and culture."1

In addition to the conventional methodologies used by the World Bank, the Communication-Based Assessment (CBA) implemented and/or monitored by DevComm can help obtain a better understanding of the dynamics of the development initiative. This research methodology implies a two-way process to initiate and maintain information flow among practitioners and stakeholders. Through the CBA, development professionals recognize the initiative's environment; make adjustments prior to project implementation; bring certain stakeholders into the process; and identify and bridge information and communication gaps.

\section{Situational Knowledge}

The CBA is an important complement to the traditional cost-benefit analysis of the project and the socio-demographic profile of beneficiaries, which then World Bank typically undertakes. The CBA provides the task managers with a situational knowledge and political

1. Joseph Stiglitz, "Public Policy for a Knowledge Economy," The World Bank Group. 
risk analysis that they can use to reshape their strategic approach to a country and to individual development projects. With its capture of empirical information related to the social, political, cultural, and institutional context of a development intervention, the CBA also determines the role that communication can play.

In communication terms, "'situational knowledge' refers to the ability to appropriately and effectively communicate in a specific situation." 2 This situational analysis is based on two aspects:

The facts: observable aspects, such as societal structure, political system, power relationships, among others.

The perceptions: the images that prevail in society, among both individuals and organizations, about the different actors in development projects, including the World Bank.

The second factor, perceptions, strongly shapes both the design and the implementation of the development initiative. Projects undertaken without the guidance of relevant stakeholders' perceptions and expectations can represent a weak approach to development. Kaufmann, Kraay, and Zoido-Lobaton (1999) developed a cross-country study in more than 150 countries, which concluded that subjective perceptions can have significant influence in future economic outcomes. The CBA offers situational knowledge, which helps Bank staff and other practitioners to make better decisions and to decrease the risks inherent in projects due to social and political factors and to poor communications.

\section{Socio-political Analysis}

The CBA performs a socio-political environment analysis that identifies key actorsindividuals and groups - in a society and their sources of influence, interests, resources, and relationships. Various analytical tools, like public opinion polling, assist decision makers in governments, development institutions, the private sector, and NGOs to understand the stakeholder dynamics at the country, sector, and project level. The CBA identifies pre-reform, political or economic, potential influences of change in society: the media, NGOs, universities, think tanks, ethnic, and religious groups. Socio-political analysis used as a communications assessment tool can uncover the range of channels for action to achieve desired outcomes.

Through systematic analysis of external actors, local leaders, pressure and interest groups, and cultural influences, one can capture the relationships among key internal and external actors and between those groups and government authorities. The CBA also provides practitioners with an understanding of stakeholder groups relative to their degree of support for the government, for a specific policy (such as reform), or for their degree of impact on the policy process.

Currently the World Bank is not undertaking socio-political analysis in a systematic, structured fashion. There is a tendency within the institution to view socio-political research

2. K.K. Reardon, Interpersonal Communication: Where Minds Meet (Belmont: Wadsworth, 1987) quoted in Windahl, Signitzer, and Olson (1992). 
as "soft" research - the usefulness of which is not adequately and widely understood. In addition, a perception exists in the Bank that socio-political analysis is too political. Sociopolitical analysis is crucial, however, because any Bank loan or development intervention, leading to reform or not, has inherent political ramifications. Expenditure controls and allocations create new winners and losers on the political as well as the economic side. Funding for individual projects and broader adjustments, for example, economic reform, education reform, or privatization, affects both electoral politics and the political economy.

\section{General Application of CBA in Reform Cases}

CBA and its socio-political analysis can lead to a more comprehensive and strategic use of communication for reform. It is a tool for social transformation, behavior change, improving understanding, and consensus building. A growing body of empirical evidence proves that using strategic communication in reform programs can substantially reduce political risk, inform project design, and promote acceptance of the reform.

The CBA, socio-political frameworks, and related approaches provide information to guide reformers on the selection, management, and expansion of stakeholders' interests that constitute the basic support for the reforms. Interventions, such as audience segmentation, polling, and behavior change mapping, assist in the design of a reform agenda. These tools indicate how to spread the burden of adjustment more evenly without harming supportive coalitions and how to sequence measures to compensate or convince those who stand to lose something from the reforms.

The CBA helps set priorities for reform programs by identifying where early gains can be made or by indicating which types of reform have the greatest chance of success. Joan M. Nelson, Noel Ramirez, Marc Lindenberg, and Benjamin Crosby, among other authors reveal the value added of socio-political analysis for implementing reforms. The sociopolitical analysis in the CBA can help reformers understand who belongs to their "coalitions" of support, in order to sequence reform programs in a manner that maintains and expands support among key groups.

As a powerful set of tools for a government that is mounting a reform program, a CBA can help determine whether the government has enough of a political base to continue current reform policies or to embark on new ones. If the appropriate analysis is made, developing countries can save valuable resources by avoiding implementing projects that may promise high economic returns and technical sustainability but which would ultimately suffer from adverse political environments and lack of public support.

In addition, the CBA evaluates the varied reactions of different stakeholders to the same development intervention. For example, during the CBA for the West Africa Gas Pipeline, the DevComm team determined the range of critical issues for key stakeholders: in Ghana it was the financial viability of the program; in Benin it was compensation; in Nigeria it was the extraction of the gas from the Niger Delta area, where there are on-going questions about human rights and land titles. Parliaments in all of these countries were concerned that they were not receiving the full information they needed for their legislative programs. ${ }^{3}$

3. Paul Mitchell, BTOR West Africa Gas Pipeline, 2004. 


\section{Figure 2. Analytical Work of CBA}

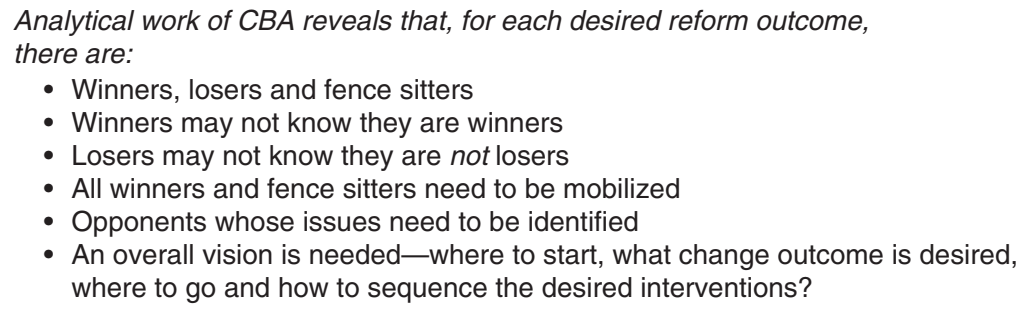

Reforms are highly contextual to country, sector, issue, time, project, and the prevailing international environment. Individual reforms in each country have different sets of supporters and opponents existing in various political, social, and cultural contexts. Trade unions may oppose economic reform; yet support health or education reform. In different circumstances, unions can be proponents, opponents, or mediating institutions. In the water reform program in Ghana, the Trade Union Congress was opposed to the reforms, yet the union representing utility workers supported the reform program. Similarly in Ghana, the NGO most opposed to the water sector reform program was a partner in a World Bank financed land reform program.

Country typologies are useless: reforms are contextual along every axis within and between countries. There may be similar elements, but these are only apparent after the analysis related to the specific reform objective has been completed. Broader societal mapping is necessary to assess the social norms, culture, citizenship skills, ethnic factors, and political values.

In the past, the World Bank promoted reforms solely through policy or administrative tools, such as loans and technical assistance to governments. In the absence of sufficient understanding of the cultural, social, and political context, these tools alone have not achieved the desired results. A thorough understanding of the context, through analytical work, identifies those reforms that are possible, swift to undertake, and have substantial pay-offs with acceptable domestic political risks. This socio-political assessment should be combined with economic analysis for designing sustainable reforms. This joint analytical work identifies a first-generation set of reforms (for example, political, social, macro-economic, and so forth). Following this, a professional communication analysis can develop a secondgeneration set of strategies for promoting change.

\section{CBA Procedure}

The CBA can be carried out either by the World Bank (DevComm) or client governments. The Bank's research is a fairly rapid (about two weeks) but comprehensive tool mainly focused on the characteristics of the development initiative and the stakeholders' perceptions and attitudes towards it. The main objective is to provide new and different information 
to the World Bank team and/or to the government to better understand the constraints to success and the need to adjust concept/design of the development initiative.

The diagnostic employed by the CBA, combined with desk research, provides enough information to create strategic communication guidelines, requiring no additional studies. At other times, complementary research is done by the client usually with the technical assistance of DevComm. This further public opinion research is a more in-depth perception exercise, and its main objective is to identify the stakeholders' needs regarding the development initiative, as well as to measure their perceptions and expectations. This includes more rigorous methodology and tools such as surveys, focus groups, and other qualitative and quantitative research methods and tools. The results of the polling and other in-depth research are combined with the preliminary results found in the diagnostic to give the client the necessary information to proceed with design of both the development initiative and the related communication strategy.

In either case, the information obtained by the CBA-both diagnostic and in-depthdepends on the nature of the development initiative. In the case of public policy or public reform initiatives, the CBA delivers a broader understanding of the relevant political context; the government's communication capacities via its constituencies, stakeholders, other agencies, and its own inter-sectoral governmental coordination. Alternatively for a specific project or program to be implemented in a particular sector, the CBA employs a narrower approach, focused on project's technical characteristics and on design and implementation of the project's communication component. 



\section{Opening the Dialogue: Components of the Communication-Based Assessment}

\footnotetext{
he CBA brings relevant information in four key areas of analysis to assist in decisionmaking and to adjust in the design and implementation of development initiatives:
}

Governmental and political risk analysis,

Stakeholder analysis,

Media, communication research environment, and local capacity, and

Social and participatory communication analysis.

A complete CBA raises a set of questions in each of these areas. Depending on the research objectives, the nature of the development initiative, and the audiences to be reached, the research team can choose among the potential questions. The final outcome of these analyses provides enough input to develop an initial strategic communication guideline. This plan identifies the areas of communication that need emphasis and the research variables to consider for more indepth analysis (through public opinion polls to identify magnitude or through other qualitative and quantitative tools).

\section{Governmental and Political Risk Analysis}

Public policies and development interventions cannot be effective without an understanding of the political environment. The CBA provides details on political risk, transparency, communication capacity, institutional support, human resources, and legal considerations. 


\section{Political Risks of the Reform, Policy, or Project}

The opposition of key political actors can affect the design and implementation of the project. It is critical, therefore, to anticipate the risks that the reform or project presents to the status quo for the political actors in the system. This is not only a matter of identifying the key politicians, but also the degree of influence they might exert over the project. The analysis must be attached to the general perceptions of the government success in delivering services, programs, and achieving results. Furthermore, the development initiative should identify and engage a political champion who could generates favorable public opinion around the development initiative. Several initiatives have failed to identify appropriate political champions, which in turn has led to public mistrust and lack of credibility in the process.

Interestingly some legal frameworks may need to be changed prior the implementation of a project. This step becomes a bottleneck if there has been insufficient communication with internal governmental actors, such as the executive cabinet or parliament, among other political leaders. It is interesting to analyze the political behavior of parliaments faced with approving loans for projects. DevComm research indicates that about 80 percent of countries where the World Bank is active have parliaments that must approve all World Bank initiatives. At the macro level, the CBA can track the political tendency to support or oppose World Bank operations in the country.

\section{Understanding Government Approach in Past Initiatives}

Through a review of secondary sources and in-depth interviews of some key actors, the CBA provides information about past experiences in similar projects and the legacy these have generated among stakeholders. This analysis helps the task manager obtain a more accurate idea of a government's pattern of dealing with similar topics. Knowledge about prior communication experiences assists in the transfer of knowledge to new governments, eliminating the need to start from ground zero. This stage of analysis is crucial to understand public perceptions about particular issues. This understanding is of particular importance in privatization projects, where past experiences define how upcoming projects are perceived.

Campbell-White and Bhatia cite the case of Senegal where the privatization program came to a halt because the there was no consensus in favor of privatization when it was launched. Politicians, employees of public enterprise, and the general public resisted the concept of privatization. In analyzing the communication aspect of this initiative, the authors noted that there was no public announcement of the policy; only weak efforts to involve stakeholders in the reform process; and feeble attempts to address directly people's concern about how privatization would alleviate poverty. Hence, the outcome-strong resistance to privatization-was hardly surprising.

\section{Government Capacity to Communicate with Stakeholders}

An analysis of the government's traditional model of communication with stakeholders is crucial to reveal how it might shape the communications activities of development projects, public sector reforms, and other governmental agendas, which World Bank operations support. 
A government's ability to communicate effectively with its people is the key to the success of its development agenda, which includes stabilizing and building the macro-economic framework; enhancing transparency and good governance; improving sector development (health, education, agriculture, transportation, and so forth); building consensus among politicians and stakeholders for development policies. Governments with low levels of communication infrastructure and strategies or with past failures of communication strategies for reform programs can face more limitations in conveying their messages and intentions to society.

\section{Institutional Support for Development Communications}

The institutional analysis reveals the understanding of and support for the role of communication within the government agencies responsible for the development initiative. Without such support, money may be wasted. A result, for instance, could be Terms of Reference for firms that do not address the communication needs of the project and overbudgeting the communication component with unnecessary advertising campaigns. In addition, political will for an initiative can be lost. Within the institutional support analysis, the "champions" are identified along with their level of knowledge and willingness to communicate with different audiences.

This analysis helps build the local ownership needed for decreasing potential political barriers. It also examines the structures of government to determine whether the organization is appropriate to support the communication intervention or whether this also needs reform.

\section{Human Resources to Design, Implement, and Evaluate Communication Strategy}

One of the main challenges country clients have is to properly address the communication component in a project and to identify the human resources needed to accomplish the task. It is important to identify key public officials who can assume the technical and managerial responsibility for implementing the communication strategy.

Traditionally the Press Office or Public Relations Office of a governmental institution is in charge of implementing activities related to media, events, and announcements, among other dissemination activities. Strategic communication for development requires a different approach. Either the project must strengthen the existing office in charge of the dissemination and information component, or new Terms of Reference are required to bring in additional human resources to take charge of the process.

Sometimes, governments have the human resources to design, implement, and monitor the communication campaign, and just a few services are outsourced. Building government capacity contributes to the sustainability of communications activities as a support mechanism for ongoing development projects. These professionals are not only the liaison between the World Bank staff and the firm or consultants in charge of executing the strategy, but they also have responsibility within government for carrying out programs. Their position allows them to be the "ears on the ground" to monitor the communication activities of the project. 


\section{Box 1: Governmental and Political Analysis (Issues to be Covered by the CBA)}

Political risk of the reform, policy, or project

- How cohesive is the Cabinet? What are the political interests that could affect the normal implementation of the project/reform/policy?

- What is the nature of the relations between the executive and the legislative branches? Are there opposing views?

- Who are the main political actors who should be persuaded/involved? Does the initiative have a "political champion"? What do the audiences think about him/her?

- What is the relevance of the initiative within the government's agenda? Can the initiative be properly positioned within the key government institutions? Among key political actors?

- Have there been any public statements of the opposition related to the initiative?

- Has the project been discussed in a parliamentary commission? What has been the position of the opposition? What actions have been undertaken to improve project positioning in the parliament? Which laws need to be approved to move forward?

- How much trust/popularity does the government have? What are the main causes? What level of credibility does the implementation agency have?

- What was the turnout during elections? How legitimate is the present government/cabinet minister? How powerful is the counterpart minister internally? Is there a strong civil service (not politically appointed) supporting the project?

\section{Transparency in similar initiatives}

- What are the past experiences in communicating similar reforms, policy, or projects?

- Which agency was in charge of implementation? Which were its main allies? Its main enemies?

- How are they perceived at government/political level, externally?

\section{Government capacity to communicate with stakeholders}

- What kind of experience in communicating policies does this government/agency have?

- What are the policies for communications and media relations?

- Does any other agency revise the communication policies of the governmental agency under which the project/policy falls?

\section{Institutional support for development communications}

-Is there any central government public communication/information structure? Where is it located (level of influence) within the government? To whom does the unit report?

-Are there sector-/agency-level and local-level communication structures? Are there geographically and organizational decentralized communication services?

-What are the relationships among the various communication structures?

-Up to what level in the communication structures are the appointments political?

-Does the implementation agency understand and "own" the initiative and its various components? Does it support the communications activities for the reform/policy/project, or does it use them as "potential propaganda" strategy?

-Where did the request for the communication component come from? World Bank or client?

- If the World Bank suggested it, was there any resistance?

-Is the client willing to borrow for the component or use grant money only?

\section{Human resources to implement and evaluate communication strategy}

- Does the government agency have a communication strategist or a press official?

-Does this official have a team? What kind of professional background do they have? What are the official's main activities in the agency? 
Box 1: Governmental and Political Analysis (Issues to be Covered by the CBA) (Continued)

-Does this team have previous experience in implementing strategies for the government?

- Can the communication office implement a communication strategy for the project? For hiring and supervising a firm? Can the team develop indicators for result or impact evaluation in communication?

\section{Legal framework for communication activities}

-What is the legislation concerning freedom of expression and classified documents?

-Does the legal framework limit communication performance? What are the laws for example related to criminal defamation?

-Does the legal framework restrict the government communication budget?

In some countries, DevComm has trained government officials in the development communication approach and guided them when implementing communication activities. Terms of Reference for further communication research and subsequent strategic communication design and implementation are written with the government communication or technical team.

\section{Legal Framework for Communication Activities}

Analyzing a project's legal framework and the country's broader approach to information flows is crucial to defining the level of information that can be disseminated through the mass media (television, radio, newspapers). Communication objectives, like overall project objectives, must be made with reference to the legal framework. The legal environment can affect the type and intensity of possible interventions and may constrain the dissemination of messages through the mass media (certain government systems could limit communication interventions). In such cases, alternative communication tools should be developed and implemented.

\section{Stakeholder Analysis}

Stakeholder analysis is one of the most complex and important components of any development initiative. It assesses not only stakeholders' acceptance of the government but also their perceptions and the priority they place on the development initiative. Identifying, disaggregating, and tracking stakeholders' perceptions and expectations leads to a better understanding of the opportunities and limitations of the project. The information the CBA reveals includes audience segmentation, identification of opinion leaders, and recognition of relevant social topics, similar experiences, and expectations.

\section{Segmenting Stakeholders and Audiences}

The project must identify its main beneficiaries and other key actors both within and outside the country. These include "hidden" stakeholders who have particular interests that 
might affect the implementation of the project. Mapping stakeholders helps to prevent the unexpected by providing a clear idea of the potential degree of influence each group has toward the project. Based on the stakeholder analysis, the development initiative can define its main audiences and those audiences to be addressed by the strategic communication campaign.

There are two major strategic advances in the segmentation and targeting of messages, according to Rice and Atkin (2001). The first implies segmenting the audiences according to their importance and receptivity to the messages. For instance, the direct beneficiaries of any given project-properly segmented by age, gender, or other relevant criteriabelong to this segment. The second refers to segmenting audiences by predisposition and ability. In this case, one community leader who is not directly affected by the project but has the ability to influence relevant groups might be considered as an audience as well. CBA brings enough information to develop a strategic approach to addressing messages to the identified and segmented audiences according to their interests and expectations.

\section{Identifying Public Opinion Leaders or Allies}

Societies listen best to their own leaders. These can be politicians, journalists, political actors, civil society representatives, religious leaders, and artists, among others. The leaders need to be identified to understand their position on the development initiative, if it exists, and to analyze the possibility of them becoming allies for the development initiative, if necessary.

Opinion leaders can become a "third voice" supporting the development initiative. This voice is particularly important if the initiative's key political champion has low credibility or if the initiative is not favored by public opinion. For example, communication (or educational) campaigns for health projects, especially those addressed to teenagers, depict the "successful teenager" in the figure of popular singers, athletes, and actors.

In addition, institutions working within the same sector as a project can be allies if they do not perceive a threat from the project. In most cases, the institutions that feel threatened by a project become opponents of the initiative. If a project does lead to competition, preventive actions and targeted messages can be prepared to avoid public confusion.

\section{Recognizing Socially-relevant Topics}

Studying stakeholders' social dynamics allows the project staff to become aware of people's priorities and values. These values are the driving forces of the society and may influence stakeholders' perceptions and their understanding of any relevant issues that may or may not be directly related to the development initiative.

It is important to establish the political and social links among groups. For example, do NGOs have internal connections with the political structures and external ones with other NGOs? Is the trade union affiliated with a political party or media organization? In addition, the CBA provides preliminary insight into the fears and myths that may surround the project and the sources of information people trust on the related issues. Other targeted public opinion polling or in-depth research can complement this initial analysis later. 


\section{Understanding Expectations and Perceptions}

The CBA provides a general panorama of key players' expectations related to the development initiative. The analysis takes into account the political promises made and the level of acceptance and confidence the government enjoys in the society. One of the main missteps of projects is the failure to measure and then to manage expectations. For example, if people expect that a power reform will bring benefits to them within one year, yet the project managers know these benefits will not accrue for five years but do not manage expectations accordingly, then people will believe the project has failed when they do not see the benefits after one year. While a CBA can provide an initial review of these expectations, further targeted polling presents a deeper view to be used as part of the project or policy design and also to develop a baseline for both project performance and communication strategy design.

\section{Recognizing Reactions to Similar Experiences}

The CBA conveys information about public perceptions related to similar project or reform experiences. People are more likely to reject initiatives that remind them of past negative outcomes, especially those within the same sector. Analyzing these experiences helps to determine public perception and to anticipate possible resistance to the project or reform. Tracking the perceptions, expectations, and practices gives a picture of the potential "behavioral path" of the stakeholders for the development initiative.

\section{Media, Communication Research Environment, and Local Capacity}

\section{Media Environment}

Two steps help to determine the media tools needed for different target audiences: identification of the channels each segment of society uses to receive and disseminate information and evaluation of the degree of trust existing in each channel. Radio, TV, and newspapers are the three most common mass media channels. Not all media or channels, however, are useful for the purposes of development communication. Methods outside of the mass media can be effective. While advertising and billboards are options that reach broadly into societies, face-to-face interventions might be better to reach many groups of stakeholders. The CBA's media analysis provides a good picture of different stakeholders' reasons for using specific communication channels; their level of trust in their sources; and the expectations generated by receiving information through mass media channels.

A review of past project experience is useful. In a labor training program for youth in Peru, for instance, whereas radio and newspaper were deemed as the most widely used channels, the communication strategy focused on local/district based radio because the media analysis showed this type of radio had the broadest reach and the most credibility among the youth. Media analysis frequently shows that people in rural areas listen to national radio stations, broadcasting in vernacular languages, while urban dwellers listen to private FM stations delivered in a second language. Some people may review all three main media channels in order to develop a full picture of development issues. For others, 


\section{Box 2: Stakeholder Analysis (Issues to be Covered by the CBA)}

\section{Segmenting stakeholders and audiences}

-Who are the internal and external stakeholders related to the project? Will they be winners or losers? What is their political influence? Do they know they will be winners? Do they know they will be losers? What are their issues?

-Who are the potential beneficiaries? Who might be adversely impacted?

-What are the relationships among these stakeholders? Power relations?

- How can stakeholders be divided into manageable groups? Does the general trade union federation, for example, have a different view than the specialized unions who represent workers directly affected by the initiative?

\section{Identifying public opinion leaders or allies}

-Do the present leaders drive the project demand? If not, who should lead it? Why?

-Who should not be involved in the process? Why?

-Who are the partners or potential partners in the program/project?

-What institutions or NGOs are working on the same sector? Can alliances be built with those potential partners? What are the risks?

- Have supporters and opponents been identified?

\section{Recognizing socially-relevant topics}

-Regarding the problem that the development initiative is trying to resolve, what is its position/ priority in people minds?

-What is the link between the initiative and people's priority concerns?

- Can people identify and understand the benefits of the initiative related to their concerns?

- Is the development initiative considered among the alternatives that people mention?

\section{Understanding expectations and perceptions}

-What are the expectations the project or reform has generated among stakeholders? Has any opinion or attitudinal research been done? If so, has it been reviewed for implications to the project or to determine additional needs? Have the results been included in the project design?

-What is the opinion about the governmental agency in charge of project implementation? Could this opinion affect the project?

-What activities could obtain public support for the agency performance? What are the different scenarios? Do people understand the general benefits and disadvantages of the project? What are their opinions about the process? Is there public support for the project? Is there any quantitative data on this aspect?

-What are stakeholders' opinions about the political actors involved?

-Is there any other project that, in people's minds, competes with this project? How?

-What are the risks people identify with the project? What do they see as the strengths of the project?

\section{Recognizing reactions to similar experiences}

-Is there a past history of similar projects? What do people associate with these?

-What associations (institutions, people, models, etc.) do people make with the current project?

-What aspects are remembered as positive? Why? (Evaluate the arguments.)

- Have experiences with past projects created any sectoral relationships in people's minds? 
media may only be the third source of information after other channels of information, such as word of mouth or web-based chat rooms and services.

During communication work in support of economic reform in Kuwait, DevComm found that there were only about 260,000 households registered to Kuwait citizens-the several million other residents in the country are guest workers. At this scale, information could be sent directly to the households of Kuwaiti citizens through the mail without the mediating influence of the media. Additional studies show that the majority of key opinion leaders get most of their information about the World Bank and its projects from its web sites and not from the media.

\section{Media and Government Relationship}

In many countries, the media is owned by the state (usually broadcast) or by large families (usually newspapers) with strong connections to political parties. Research by the World Bank (2002) shows that about 90 percent of global media is controlled in one of these two ways. Media businesses are based on advertising. In developed countries advertising comes primarily from the private sector, which invests significant amounts of money in newspapers, radio, and TV. This is not the case in all developing countries. With the exception of resident transnational business and some larger local business organizations, the government tends to be one of the major advertisers. This situation can affect the coverage of a development project and thus the success of its implementation. A general mapping of the relationship between media and government can help identify a priori possible scenarios.

\section{Economic and Political Interests as Information Drivers}

The influence of government in the media business and vice versa is significant to the development process. Political and economic interests can shape the provision and drive the dissemination of information. It is important to identify these intricate relationships, to reveal the potential messages sent, and to discover possible alternative media channels to balance the influence or pressure on some media organizations.

\section{Quality of Analysis and Provision of Information}

Besides the economic or political influence of corporate media owners, journalists also have a significant influence in shaping public opinion. Whether or not they have accurate information, journalists may have a bias for or against a development initiative, which may affect their reporting. The level of analysis provided through the media helps to define and to shape perceptions and expectations among the public. The media rarely provides the full details about projects because governments often do not supply clear, sufficient, or timely information. The press offices do not address press releases with an overall strategic approach to the development initiative. The CBA identifies all these relationships. In some cases, it also identifies the need to develop and deliver training for journalists to better understand the development initiative. 


\section{Coverage of Media}

For development purposes, it is important to know in empirical terms the level of penetration each media channel has in society. Combined with messages and audiences, this sets the parameters for the communication campaign. For instance, there are often large distinctions made between how rural and urban dwellers receive information. There may be large distinctions among urban dwellers' use of radio, television, or newspapers as their primary source of information. Most countries have a private sector polling company, which, reviews and disaggregates the media habits of the country at least annually. While this work is done for the advertising industry, the information is of equal value for a media analysis of the society. This type of study also identifies the degree to which people listen to media delivered from outside their country. People in Africa and South Asia, for example, listen to the BBC World Service more than they listen to local media outlets. For better impact, communication programs and costs can be adjusted by using the most appropriate channels for the specific target audience.

\section{Alternative Means of Accessing Information}

Do people access information through means other than the mass media? In specific countries, depending on the topic to be disseminated, web-based sources of information or SMS text messaging are used more often than traditional media. In other countries depending on the topic, word of mouth, direct mail, posters, billboards, and organized discussion groups may be more effective ways of reaching people. Often word of mouth, for example, talking to village women at the water pump, may be a more effective way to reach people than traditional media.

The level of education, socio-cultural behavioral patterns, gender issues, traditional sources of information, daily habits of the audiences, among other considerations, should be reviewed before identifying or designing an alternative information mechanism. Furthermore, testing the messages and the channels of dissemination can guarantee the communication strategy's desired impact.

\section{Communication Capacity in the Country}

It is critical to know how much the private sector, universities, and NGOs, among other organizations, can deliver in terms of communication-related activities. Are there organizations that deliver polling, and what is their relationship to international companies? Are there companies that can develop and deliver communication strategies and campaigns? Are there advertisers, web designers, graphic designers, printing companies, and individual communications consultants in the country? Are there people at the universities or NGOs who can do some of this work? Since implementation is done locally, if the government lacks the capacity, the CBA identifies and assesses the local capacity and suggests some combination to achieve the communication goals. Options include hiring individual consultants who work with an international consultant and hiring a single firm or a consortium of firms, private or NGOs to fulfill the service required, among others. The goal is to develop an integrated vision of the magnitude of the work and the best alternative possible for the country team to achieve it. 


\section{Box 3: Media and Communication Research Environment Analysis (Issues to be Covered by the CBA)}

\section{Media environment}

- What are the most credible media channels (radio, TV, newspaper) in the society? Are there private sector companies that do polling, communications, and media analysis for advertisers?

-Are there any journalists with credibility among the public?

-Are there alternative media which people access? Where are they?

- How do people receive information? What influence do these channels have on their actions? - look at the influence of each channel in terms of behavior change

- ascertain informal methods of communication

\section{Relationship with government}

-Does the government invest money in advertising? How often? In which media?

- Is there any relationship between members of government and the media?

-What has been the position of the media in similar development interventions? Who are the natural media allies?

\section{Economic and political interests driving the provision of information}

-Who owns the media businesses in the country? What other business do they own? Are there some potential conflicts with the project?

- What is the political tendency of the media?

\section{Quality of analysis and provision of information}

- Does the government provide information to the media? How often? What kind of information?

- How do journalists obtain the information? What are their information sources for the issues related to the development initiative?

- What press or communication materials has the development initiative disseminated among journalists? What are the messages? (Evaluate the messages in terms of strategic objectives of the development initiative.)

\section{Coverage of media}

- What media channels exist in the country?

- What has been the experience of using the media channels in similar initiatives? Has there been an impact evaluation of communication in those initiatives?

- What could be the most suitable media combination to reach the main stakeholders of the initiative? Does the budget allow for media planning? What alternatives do we have?

\section{Communication capacity in the country}

-Are there communication research companies? Do they undertake social or attitudinal marketing? Do they have experience in similar projects? What are the approximate costs?

- Are there private marketing, advertising, or communication companies? What is their track record and capacity? What are the approximate costs?

- Are there individual consultants who can design and implement communication campaigns?

- What are the most active and influential private sector (profit and non-profit) public communication structures (public relations and advertising companies, universities, think tanks, advocacy groups, etc.)?

- Have any of these organizations delivered public communication programs with similar objectives? 


\section{Social and Participatory Communication}

The participation of beneficiaries and main stakeholders in development initiatives leads to better and more sustainable results. In his report "Assessing Aid", David Dollar states that projects that involved beneficiaries had a 70 percent success rate. Those that did not had a 10 percent success rate. Consultation implies the active solicitation of stakeholder perspectives to help shape the formulation of projects and policy, ensuring that the mechanisms are in place for a two-way flow of information and for building consensus among stakeholders about the development agenda (Mozammel and Barbara Zatlokal 2002). The CBA approach provides task team leaders and World Bank staff with the social mapping needed to include the participation of beneficiaries from the beginning of the project.

\section{Social Forms of Information}

Social spaces exist for the interchange of certain kinds of information that cannot be disseminated through the mass media or traditional communication process. The CBA identifies these alternative methods of communication and incorporates them into the decisionmaking process to guarantee adequate feedback. In addition, civil society organizations and representatives of beneficiaries are taken into account to develop the communication process without breaking the informal (or formal) system they currently use.

When considered as part of the development initiative design, the identification, engagement, and possible strengthening of the traditional social mechanisms of decisionmaking may yield significant results. This can facilitate stakeholder's ownership of the initiative by valuing the stakeholders' current mechanisms and by avoiding conflict through creation of new mechanisms. If a space for decisionmaking or social discussion does not exist in the sector where the development initiative will be implemented, new space should be established. In this case, the representation of the civil society organizations, government institutions (central and local), and especially the beneficiaries play a critical role in facilitating the sustainability and accountability of the initiative.

\section{Participation through a Two-way Communication Process}

Project sustainability is based on the real participation of beneficiaries and other stakeholders involved. There is a tendency to incorporate beneficiaries' participation after decisionmaking is complete and implementation begins. This represents a weak two-way communication process. To integrate their expectations, needs, and perceptions, the project should include beneficiaries from the beginning of the project cycle. The CBA helps this inclusion and promotes authentic participation in the development initiative. In addition, transparent and clear communication mechanisms should be developed to verify the messages and to ensure beneficiaries are correctly understood.

The capacity to gather feedback from the stakeholders and successfully incorporate it into the design and/or implementation of the initiative is a major weaknesses and a main challenge for a development initiative. The establishment of mechanisms of participation is just one area of the participatory process. Without proper communication, these mechanisms of participation can create false expectations among the stakeholders, which can lead to the ultimate failure of the project or reform. 


\section{Box 4: Social and Participatory Communication Analysis (Issues to be Covered by the CBA)}

\section{Social forms of information}

-What are the spaces (schools, churches, etc.) of social interaction for the community?

- How are the beneficiaries represented? How are those leaders elected? Is the development initiative aware of these activities?

- How does the community take decisions (meetings, committees, etc.) about common problems? How often? Have they discussed the topics related to the project in their meetings? What did they agree on?

- Have the beneficiaries produced some communication products in their communities? Can the project use these as communication mechanism?

-Are there informal organizations in the community? What kind of groups? What are their main activities?

\section{Participation through a two-way communication process}

- Have the beneficiaries been consulted about the initiative? When? How were they informed? Which materials or messages did they receive? Which institution produced them? What was the final outcome of the consultation? What are the next steps for strengthening communication/ interaction with them?

- How do the beneficiaries participate in the project? When did they start this process? What are the communication mechanisms they use?

-Is the local political culture familiar with the concepts and outputs of the project?

\section{Building consensus}

- Has the interest of the formal and informal community/local leaders been identified in project benefits/changes? What is the relationship among them? Have they worked together on past experiences? What were the results?

- Have there been previous conflicts among these people? Current conflicts? What is the magnitude? Can they affect the project?

-What are the common points identified for starting a consensus-building project? What is the degree of commitment for negotiating?

-Does the government support the community agreements? What is the community opinion of governmental intervention? What about other stakeholders' interventions (private sector, NGO, etc.)?

\section{Identifying networks}

-Who are the champions of the development initiative? How important are they for the beneficiaries and stakeholders?

-What other institutions are participating in community development? How do they coordinate to take actions? What is the level of community involvement? How do the other institutions measure this involvement?

A challenge for the World Bank staff is to decide what actions should be taken with the feedback or information provided by the stakeholders. These data do not necessarily coincide with the financial and technical approaches used in the project. Therefore, the data could be discarded, underestimated, or simply ignored, creating a gap between the technical approach and the socio-cultural perspective of the stakeholders. Often the Inspection Panel reports show that the complaints of communities or groups are not related back into 
the project itself. Instead, the complaints relate to the project communication process both with the manner in which the local teams approached the communities and how their views were taken into consideration. To properly manage those expectations during the project cycle, the CBA provides an interesting and useful picture of the stakeholders' expectations, regarding their participation in the development initiatives.

\section{Building Consensus}

Trust among participants, transparent information, appropriate feedback, and leadership are some of the key components for building consensus. The communication strategy should implement activities to strengthen those activities, incorporating the human communication dimensions needed for negotiating among the stakeholders. As Masud Mozammel and Barbara Zatlokal (2002) point out in a World Bank report, "in order to ensure a two-way flow of information, it is necessary to take into account both internal and external factors that influence human communication." Building consensus is a process that not only involves good knowledge of human relationships and dynamics but also determines the appropriate information that needs to be shared with the stakeholders.

From DevComm's perspective, building consensus is a communication process per se that should have the appropriate approach to achieve success. The CBA provides information about formal and informal relationships among the key stakeholders; power and influence of each stakeholder; and past conflicts that might affect the future process.

\section{Identifying Networks}

At the local level, the map of different actors is useful to identify possible networks with which the development initiative might work. NGOs, church organizations, schools, and so forth are just some of these institutions that should be included in an integral development approach for a communication campaign. This part of the analysis also helps to illustrate how the actors relate to each other and to their own organizations to identify potential interests that are not evident at first glance. 


\section{Contribution of the CBA to Operational Projects}

$\mathrm{N}$ umerous frameworks exist to analyze the political, social, cultural, and economic dynamics influencing a desired reform. Through the systematic identification of problems, sources of influence, effective methods, and timing for change, the CBA framework helps to mitigate risks and to improve the efficiency and sustainability of World Bank projects. This section outlines the main outcomes provided by the CBA.

\section{Alignment of Development Objectives}

The CBA identifies the relevant concerns and priorities of the main stakeholders involved in a development initiative. It enables Bank staff to determine whether the priorities previously identified in the technical and economic analyses correspond with the concerns or expectations of the affected stakeholders. If they do not align, suggestions and recommendations from the CBA can help bridge the gap.

Without the CBA, the Bank may give erroneous advice to the client government on the perceived priorities of affected people. The role of the CBA in aligning the objectives of development initiatives to the real concerns and priorities of the beneficiaries is critical in designing projects. The following chart from the Ghana Urban Water Reform program shows, for example, that the issue of water is highly important to people. Further research indicates that the main reason relates to health issues, thereby tracking with a major Bank investment in the water sector (see Figure 3).

An additional piece of research breaks down the issue even further. Countering perceptions that the main issue with water would be the expected increase in its price, the real issue was availability. This again sets the right context for Bank investment (see Figure 4). 
Figure 3. Importance of Issues (Ghana Urban Water Reform)

Health, water, and access to education were the most personally important issues for respondents.

\begin{tabular}{|l|c|c|c|c|}
\hline Issue & $\begin{array}{c}\text { Not at all } \\
\text { important }\end{array}$ & $\begin{array}{c}\text { Not too } \\
\text { important }\end{array}$ & $\begin{array}{c}\text { Somewhat } \\
\text { important }\end{array}$ & $\begin{array}{c}\text { Very } \\
\text { important }\end{array}$ \\
\hline Health & $0 \%$ & $0 \%$ & $6 \%$ & $94 \%$ \\
\hline Water & $0 \%$ & $1 \%$ & $7 \%$ & $92 \%$ \\
\hline Access to education & $0 \%$ & $1 \%$ & $8 \%$ & $91 \%$ \\
\hline Unemployment & $1 \%$ & $2 \%$ & $9 \%$ & $88 \%$ \\
\hline Future for the country's youth & $0 \%$ & $1 \%$ & $15 \%$ & $84 \%$ \\
\hline Economic growth for the country & $0 \%$ & $2 \%$ & $15 \%$ & $84 \%$ \\
\hline Electricity & $1 \%$ & $3 \%$ & $17 \%$ & $80 \%$ \\
\hline Government effectiveness & $1 \%$ & $2 \%$ & $19 \%$ & $80 \%$ \\
\hline Sanitation & $0 \%$ & $2 \%$ & $20 \%$ & $78 \%$ \\
\hline
\end{tabular}

\section{Identification of Audiences}

The CBA identifies and disaggregates audiences, their issues and behaviors. For example, in the Ghana Urban Water Reform project, the CBA identified the main audiences as:

Politicians, in particular the majority whip, the Minister, Cabinet and members of two House subcommittees;

A set of civil society organizations including a major local NGO, which owned a newspaper and had links to a major global NGO based in the United States. There were also a set of NGOs who supported the reform program;

Figure 4. Most Important Aspect of Water Service (Ghana Urban Water Reform)

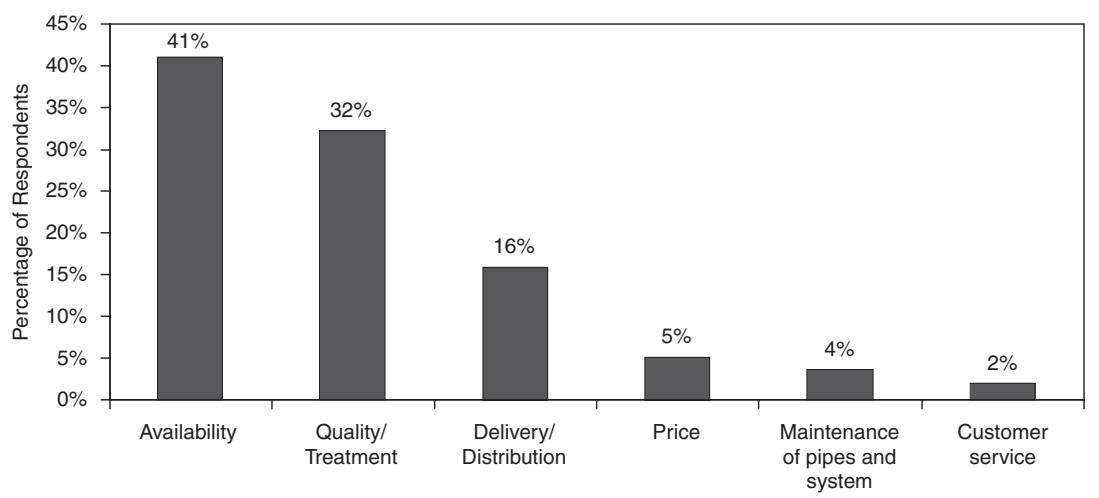


The Trade Union Congress (TUC), the union representing the workers in government utilities, and the staff of the Ghana Water Corporation.

With this case, it was important to break apart the audiences. For example, a trade union is often thought of as a single entity. In reality it can be composed of many groups, each one affected differently and with varied political interests and communication needs. In this case, while the TUC was opposed to the reform, the union representing the workers in the water utility supported the reform. Rank and file workers have different issues and needs and could be further sub-divided. On the political front, the Minister for Water had to be convinced that the reform program was supported by the public; the cabinet had to approve a change from a lease agreement to a management contract; which then had to be agreed to by the parliamentary subcommittees. Therefore, within the grouping "parliamentarians", there were very different audiences and concerns.

Another case, the West Africa Gas Pipeline, illustrates audience concerns across borders. The pipeline, starting in Nigeria, would supply gas to Benin, Togo and Ghana. Each country had a set of internal audiences highly dependent on its predominant national interest. There were some overarching audiences, such as NGOs, but this played out differently in each country. Parliamentarians were also a common audience who in this case had a common issue-lack of information on the laws and regulations they were expected to pass. The issue in Nigeria was mainly driven by an NGO that had lingering concerns related to land rights, shared benefits, and human rights issues in the Niger Delta, where the gas originated. In Ghana, the question was surrounded the economics of the project, and in Benin it was compensation. In Ghana the NGOs were mainly supportive of the project as it would use gas instead of light crude to generate power and there would be many environmental benefits.

In an example in Mauritius, the government committed to private sector participation for water and sanitation. As part of the IFC advisory services to the government of Mauritius, a CBA was carried out to identify risks and opportunities. Figure 5 shows the identification of the main audiences for this project.

In each of these countries cited, there were different audiences linked to different issues. Their level of interest and influence was dependent on the impact of the project in each place. The main audience was also different: in Ghana it was the political establishment, in Nigeria the NGO community, in Benin it was the local people affected by the project and in Mauritius the employees and consumers.

\section{Assessment and Mitigation of Social and Political Risks}

The CBA identifies the level of government support for the initiative and the resistance from opposition groups, such as domestic and foreign pressure groups, political parties, and social sectors. If this is done at the beginning of the project cycle, an assessment of the potential political issues associated with development initiatives allows Bank staff to design appropriate risk mitigation measures to facilitate the implementation of these initiatives.

There is a tendency to underestimate the potential risks posed by groups viewed as "marginal" or "irrelevant." Teams often assume that these groups are outside the target 


\section{Figure 5. Major Audiences* (Mauritius)}

\begin{tabular}{|l|l|}
\hline $\begin{array}{l}\text { Primary audiences: those ultimately affected, } \\
\text { either positively (beneficiaries) or negatively (for } \\
\text { example, those involuntarily resettled). }\end{array}$ & $\begin{array}{l}\text { CWA and WMA employees, CWA end users, } \\
\text { WMA connected costumers, water service } \\
\text { providers, people living near major infrastructure } \\
\text { work, poor and vulnerable groups, public at large, } \\
\text { small farmers. }\end{array}$ \\
\hline $\begin{array}{l}\text { Secondary audiences: those with some } \\
\text { intermediary role. }\end{array}$ & $\begin{array}{l}\text { Other ministries: Health, Fisheries, Local } \\
\text { development, Finance, Environment, Education. } \\
\text { Water Resource Unit, Irrigation authority, } \\
\text { Members of Parliament, Police de I 'environment } \\
\text { Donors: EU, UNDP. NGOs: environmental and } \\
\text { social NGOs, National Councils. Sugar Cane }\end{array}$ \\
Producers. Expatriates.
\end{tabular}

"CWA stands for "Central Water Authority" and WMA for "Waste Management Authority."

audience to be involved in the discussion about the development initiative. This is a strategic mistake. For example, in the case of urban water reform in New Delhi, a small NGO composed of a few women was dismissed as not being important. Yet because of their high-level political connections, the group was able to derail the project.

The CBA helps identify all potentially affected stakeholder groups, including those that may seem "irrelevant" at first glance, thereby assessing the relevant risks—particularly social and political. In turn, this identification of stakeholders-and the social and political risk from each group-forms the basis of a strong communication component in a development initiative. The component engages and involves relevant stakeholders and mitigates their potentially negative influences on the initiative. This component goes beyond the information and dissemination approach and involves two-way communication activities that address the concerns and incorporate the feedback of all relevant actors.

This methodology is illustrated in the Figure 6 in which the stakeholders are identified. The chart, however, also looks at the areas of conflict and the nature of the conflict. Such mapping is critical to project design, consultation design, risk mitigation, and the development of a communication strategy.

In the case of the judicial reform in Georgia, the CBA brought to the attention of the government and Bank teams the many risks involved with the modernization of the judiciary. Among the main findings, it became clear at that time the only reformers were those 


\section{Figure 6. The Reality of Institutional Settings}

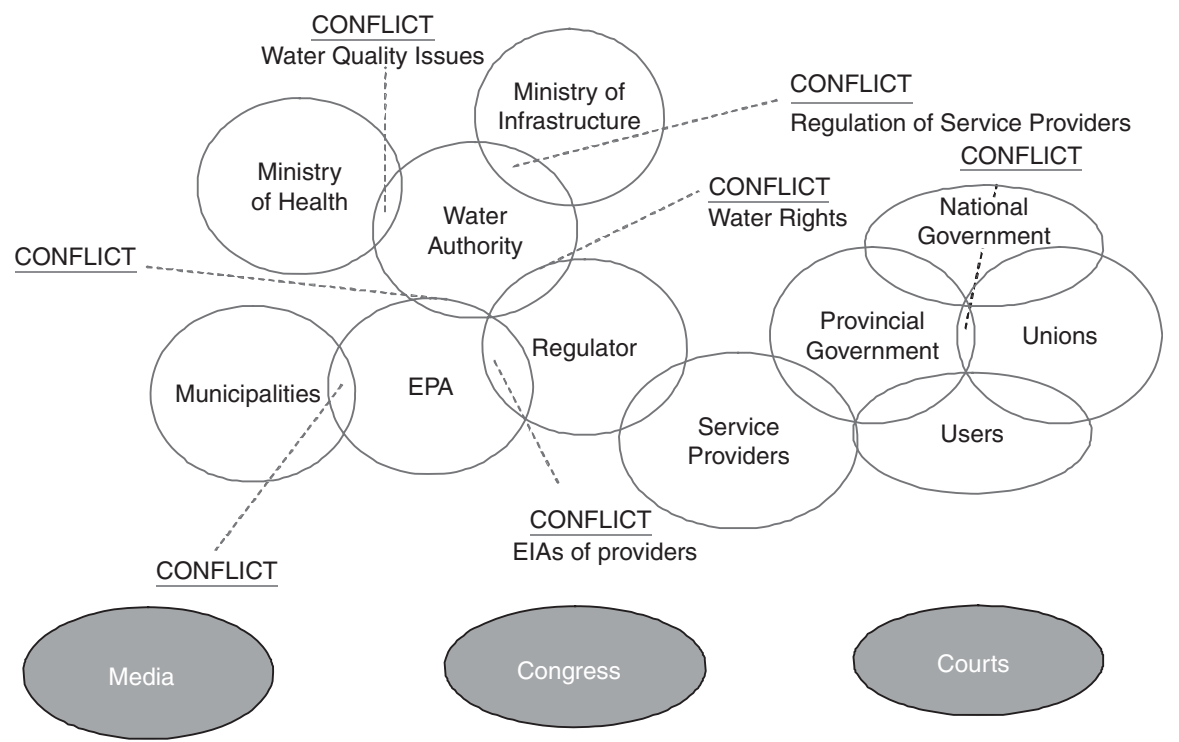

Water Sector Institutions in the Province of Buenos Aires

Source: Gustavo Saltiel, Urban Water Supply Practice Retreat, 2006.

behind the judicial reform. Hence, all those "Soviet-minded" politicians were ready to attack the judicial process, not on the merits or shortcomings of the reform itself, but because it represented the forces of change and democratization. The following chart summarizes the main risks identified with the reform.

\section{Figure 7. Georgia Judicial Reform Socio-Political Risk Analysis}

High political risk in a difficult environment

- Groups with powerful vested interests had a lot to lose from the reform (judges, legal professionals, politicians, mafia, etc.)

- Judicial reform could become the focus of a wider, mainly political, debate

- Insufficient consensus - internally and nationwide - on the need to reform

- Lack of interest and public mistrust towards the judicial system (Soviet legacy)

- Citizens resorting to "alternative" dispute resolution mechanisms (i.e. organized crime)

- Concept of "legal culture" under developed 


\section{Identification of Stakeholders' Positions}

In general, development teams tend to believe they know exactly what the stakeholders think about a topic or project. Often, development projects are designed based on these beliefs. These beliefs, however, are merely assumptions, and assumptions may not necessarily be correct.

The CBA helps Bank teams avoid making assumptions by identifying the relevant stakeholders who are affected-positively or negatively-by the development initiative. It analyzes their positions and key concerns, their relative importance in the policy process, and their relationship to institutional decisions.

For instance, in the pension reform project in Egypt, the CBA found that the consensus among the opinion leaders was that the passage of the controversial reform could not be assured without the support of key stakeholders outside the government. Therefore, there was a need to undertake consultative and consensus-building processes with stakeholders to build support for reform proposals.

One of the suggestions considered in the CBA was for the government to increase the circle of those consulted to increase the support from wider segments of society. The main risks of this activity-such as building expectations that could not be fulfilled or alienating stakeholders because the process appeared too final for their inputs to be meaningful—were identified, and specific mechanisms were created to mitigate these risks. Another output of the CBA is the analysis of the arguments and strategy of the opposition groups related to the development initiative. This feature of the assessment is crucial for framing the future messages to the stakeholders, and more importantly, for making strategic decision on how to approach the main stakeholders that might be involved in the process.

Box 5 is an example of the stakeholder analysis and the identification of their positions regarding a water and sanitation project in Mauritius involving private sector participation.

\section{Identification of "Champions" for the Initiative}

For reforms to succeed, political willingness to move forward is crucial. This is true particularly if development initiatives involve unpopular measures. The CBA's contribution to the topic of political will lies in identifying key officials and independent and authoritative third parties who could become "champions" for the development initiative.

The common pitfall in identifying the appropriate reform champions is that often finance ministers or government agencies signing the loan agreement with the World Bank are considered to be natural champions for the process. However, this narrow approach to selecting a champion may not necessarily be the most appropriate. A champion selected in this manner may not resonate with the general population or the main stakeholders involved in the process, leading to obstacles in getting the message across to beneficiaries in the civil society and other relevant groups.

The identification of suitable champions, therefore, requires in-depth research, mainly quantitative. Opinion polls and surveys exploring people's perceptions about potential 


\section{Box 5: Analysis of Critical Audiences (Water and Sanitation PSP, Mauritius)}

The agricultural sector: The agricultural sector is quite autonomous in terms of water needs. Water rights are attached to land ownership. If a license is going to be issued to regulate the usage of water, the chamber of agriculture and the sugar cane producers (whose interests are completely merged) are going to protest and appeal to their undeniable water rights.

Small agriculture producers: Without water rights, they are the most frustrated and in need of additional water resources. The Water Resources Unit has drafted an integrated plan for harnessing additional water resources with the purpose of optimizing the utilization of this vital resource. The plan includes a monitoring system capable of measuring the amount of water being extracted by the sugar cane producers. This aspect will most likely create frictions and should therefore be handled with special sensitivity.

Unions: Although only $13 \%$ of the working force in Mauritius is unionized and with the exception of a few groups, unions are not vocal as in many other developing countries, not considering their positions could cause the attempt to privatize the water sector to fail. Unions need an appropriate explanation of where the reform is leading. The Central Water Authority (CWA) union fears a reform dropped from the top without proper consultation with the labor force. Again a strong call for transparency needs to be registered. Finally, the CWA union is aware that the water sector and CWA authority need to be modernized. The Federation of Civil Service Unit believes the water sector should remain in the hands of the government. Privatization is seen as the result of mismanagement and as handled without proper transparency. Although their level of organization seems fairly weak, this group represents 70 percent of the unions in Mauritius.

Mauritius Consumer Association: The Mauritius Consumer Association is the most vocal opponent of the current billing system and tariff structure of CWA and WMA. Although they are a small organization, their capacity to organize well-articulated public protest should not be underestimated during the reform process.

The media: None of the national media is prepared to talk about privatization. Neither broadcast nor print media fully understand what private sector participation is all about and they do not know any success stories. Sensationalism prevails over objectivism. In order to avoid miscommunication, journalists will need to be contacted and involved throughout the duration of the reform process.

Elected officials: MPs and Government officials, as well representatives from local governments, need to be informed about developments in the sector and, eventually, believe they are themselves part of the reform process.

Other dissatisfied parties: On top of the normal process of information dissemination central to the government's communication strategy, particular attention in communicating the reform should be given to all those audiences that might have specific reasons to be opposing the reform. With the completion of the public opinion research study, a cluster analysis of the different segment of the population will provide additional clear cut information of all critical audiences opposing the reform that might exist.

The poor and vulnerable groups: In line with its commitment for social justice, the government will need to make sure that socially excluded and poor groups will be adequately identified during the reform and provided with a special treatment concerning the provision of water and sanitation services.

champions and how their credibility and legitimacy are perceived will lead to a more strategic approach to deciding who would lead the process.

The following chart illustrates the degree of trust in different audiences. This is important in defining who should be the spokesperson or champion for the reform program and in identifying the level of credibility he or she has among audiences. In this case, the NGO opposed to the reform was seen as having low credibility with the public while the government—as opposed to politicians—-had high credibility. 
Figure 8. Players (Ghana)

The national government, local media, and religious leaders were perceived as having the most positive impact on Ghana.

\begin{tabular}{|l|c|c|c|c|}
\hline Stakeholders & $\begin{array}{c}\text { Very bad } \\
\text { impact }\end{array}$ & $\begin{array}{c}\text { Somewhat } \\
\text { bad impact }\end{array}$ & $\begin{array}{c}\text { Somewhat } \\
\text { good impact }\end{array}$ & $\begin{array}{c}\text { Very good } \\
\text { impact }\end{array}$ \\
\hline National government & $2 \%$ & $5 \%$ & $30 \%$ & $64 \%$ \\
\hline Local media & $1 \%$ & $4 \%$ & $36 \%$ & $59 \%$ \\
\hline Religious leaders in Ghana & $1 \%$ & $5 \%$ & $36 \%$ & $58 \%$ \\
\hline International NGOs & $1 \%$ & $3 \%$ & $39 \%$ & $57 \%$ \\
\hline The World Bank & $4 \%$ & $8 \%$ & $37 \%$ & $52 \%$ \\
\hline International private sector & $2 \%$ & $7 \%$ & $46 \%$ & $46 \%$ \\
\hline The IMF & $5 \%$ & $9 \%$ & $40 \%$ & $45 \%$ \\
\hline Local NGOs & $1 \%$ & $5 \%$ & $49 \%$ & $45 \%$ \\
\hline Local private sector & $1 \%$ & $7 \%$ & $48 \%$ & $44 \%$ \\
\hline International media & $2 \%$ & $10 \%$ & $46 \%$ & $43 \%$ \\
\hline ISODEC & $1 \%$ & $6 \%$ & $54 \%$ & $40 \%$ \\
\hline Rudolf Amenga-Etego & $1 \%$ & $12 \%$ & $59 \%$ & $30 \%$ \\
\hline Politicians & & $24 \%$ & $37 \%$ & $22 \%$ \\
\hline
\end{tabular}

\section{Understanding of Decisionmaking Mechanisms}

The establishment of effective mechanisms for engaging key stakeholders in the development process is one of the main challenges faced in World Bank interventions. Yet another difficulty is the creation or strengthening of inclusive decisionmaking mechanisms and the space for dialogue.

The CBA assists World Bank teams in this effort by outlining the current decisionmaking mechanisms used by stakeholders. CBA findings can be included as input for the implementation arrangements in the project design or as part of the governance and transparency mechanisms. Along the same line, the CBA also recommends effective mechanisms for stakeholder participation based on timely provision of information and appropriate feedback collection process. These mechanisms should be included as part of the technical design of the project to promote efficient project implementation and delivery of the expected outcomes.

In the case of the Arid Lands Resource Management Project (II phase-ALRMPII) in Kenya, the CBA included a survey of 42 representatives of local technical teams (Field Extension Workers, FEW, and Mobile Extension Team, MET) from 21 districts where the project implemented community-driven development (CDD) components. The 


\section{Figure 9. Basic Organizational Communication Chart for ALRMP II* (Kenya)}

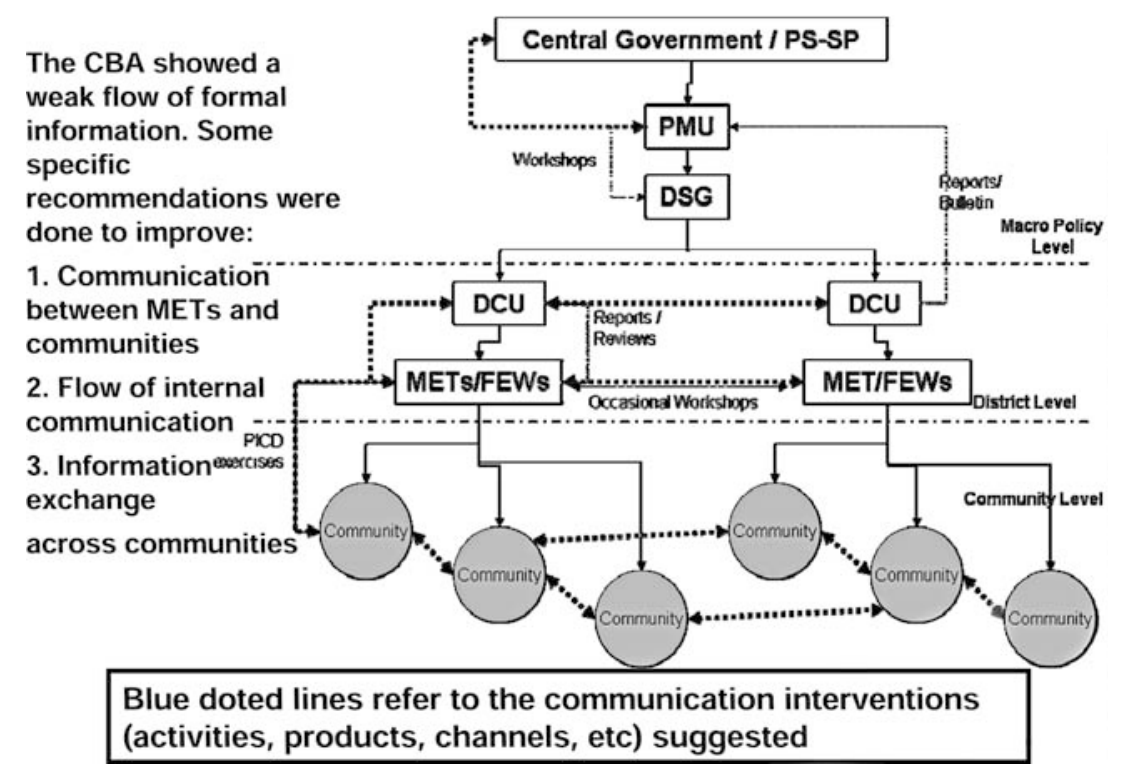

* PS stands for "Permanent Secretary", PMU stands for "Project Management Unit", DSG for "District Steering Group", DCU for "Drought Coordination Unit (Arid Lands)", MET for "Mobile Extension Team", and FEW for "Field Extension Workers."

main objective of this survey was to identify the main information gaps among the teams that limited their interaction with the rural communities in Kenya. The participants believed there were not enough channels to share information; however, the survey identified that the teams were not using the right channels to communicate with each other and the information they shared lack consistency. The teams approached the communities and provided information that was based on individual experiences. Most of them were not aware of the innovations and outcomes in other districts; some other had the information but did not share it because they did not understand how important this experience could be for their own district. The team members were unclear how to convey the successful experiences because there was no shared understanding of what a "best practice" meant. In addition, the upper management (government) did not receive this information systematically. The chart below is a Basic Chart on Organizational Communication, identifying the type of information needed to improve the teams' interaction with the communities. Moreover, the survey showed that there was a significant lack of "bottom-up" information from the local teams to the government. This situation not only limited the government knowledge of the results of the ALRMP II project but also weakened its ability to improve its natural resource management policies. 
The CBA also identifies government decisionmaking mechanisms and can assist in the restructuring that is needed for more efficient decisionmaking or to identify the potential roadblocks.

\section{Inputs for a Sound Public Communication Program}

One specific goal of the CBA is to provide inputs for a public communication program, which can evaluate the previous activities and channels; decide on the communication tools; raise awareness; and build public consensus around the development activity.

A thorough analysis and understanding of the audiences and risks is the basis of a sound communication program. The CBA identifies ways to make communication with various stakeholders more effective. It also examines the specific communication channels through which the audiences related to the project receive information, looks at the overall media environment, and determines the best mix of channels to reach the target audiences. Furthermore, it analyzes the communication infrastructure and capacity, both within and outside the government or the implementation agency, for undertaking communication activities. The main challenge for the World Bank is in determining how to incorporate these findings of the CBA in the design of development initiatives.

Figure 10 outlines the components that the CBA developed in the Bumbuna Hydroelectric project in Sierra Leone. As illustrated the communications campaign utilizes a wide variety of activities in order to achieve project success.

\section{Figure 10. Communication Action Plan Components*}

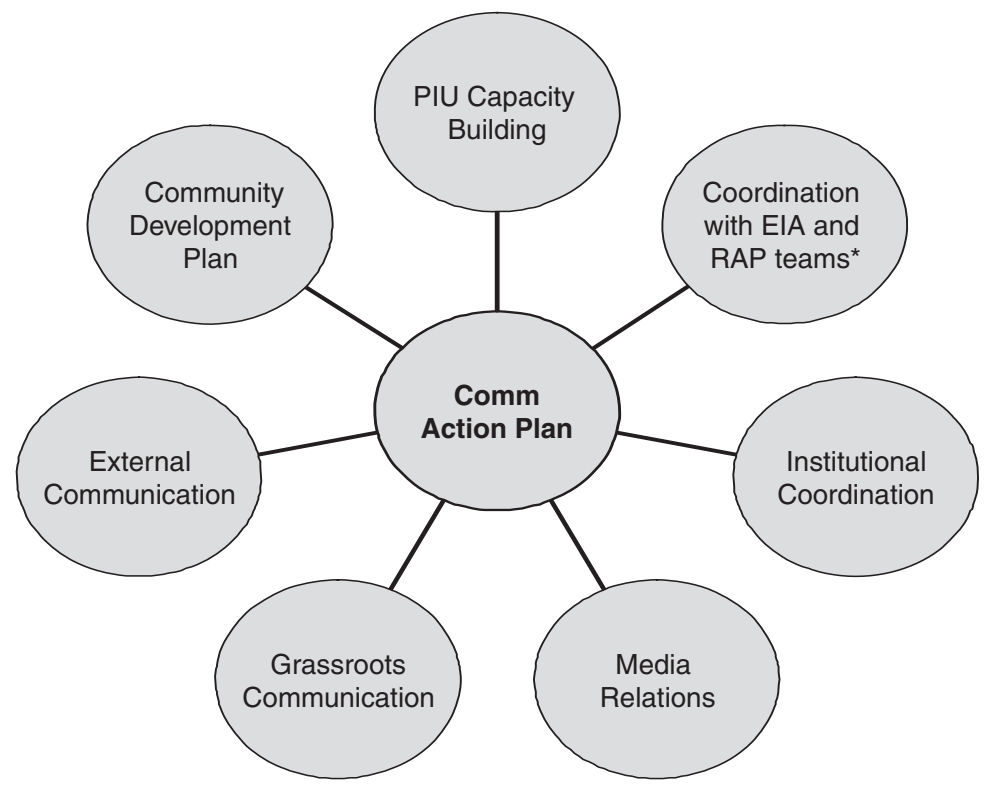

*EIA stands for "Environmental Impact Assessment" and RAP for "Resettlement Action Plan." 
Figure 11. Main Areas of Intervention (Brazil)

There are five main areas of communication intervention, but there are four preliminary areas for the Teresina project:

\begin{tabular}{|l|l|l|l|}
\hline \multicolumn{1}{|c|}{ Areas } & \multicolumn{1}{|c|}{ Example } & \multicolumn{1}{|c|}{$\begin{array}{c}\text { Used for } \\
\text { Teresina? }\end{array}$} & $\begin{array}{l}\text { Approach for } \\
\text { Teresina (example) }\end{array}$ \\
\hline $\begin{array}{l}\text { Public Information \& } \\
\text { Education }\end{array}$ & $\begin{array}{l}\text { Education } \\
\text { campaigns }\end{array}$ & Yes & $\begin{array}{l}\text { Information } \\
\text { campaign about the } \\
\text { PPP process }\end{array}$ \\
\hline $\begin{array}{l}\text { Participatory } \\
\text { Communication }\end{array}$ & $\begin{array}{l}\text { For decision } \\
\text { making }\end{array}$ & Yes & $\begin{array}{l}\text { Strengthening the } \\
\text { Community Forum }\end{array}$ \\
\hline $\begin{array}{l}\text { Communication for } \\
\text { Behavior Change }\end{array}$ & $\begin{array}{l}\text { Hygiene } \\
\text { promotion }\end{array}$ & No & \\
\hline $\begin{array}{l}\text { Advocacy and Consensus } \\
\text { Building }\end{array}$ & Pass a law & Yes & $\begin{array}{l}\text { Inter-institutional } \\
\text { communication for } \\
\text { coherent message }\end{array}$ \\
\hline Internal Communication & $\begin{array}{l}\text { Re-structuring a } \\
\text { firm }\end{array}$ & Yes & $\begin{array}{l}\text { Reducing the risk } \\
\text { of misinformed } \\
\text { opposition }\end{array}$ \\
\hline
\end{tabular}

In the case of a water and sanitation project (under preparation) in Brazil, the CBA analyzed the development objectives of the project and defined the main areas of intervention for a sound communication campaign (see Figure 11).

Important strategic decisions include how people receive information and whom they trust. The following chart illustrates the case of water reform in Ghana where most people

\section{Figure 12. Trusted Sources}

The majority of respondents trust local Ghanaian radio and television stations for their news and information.

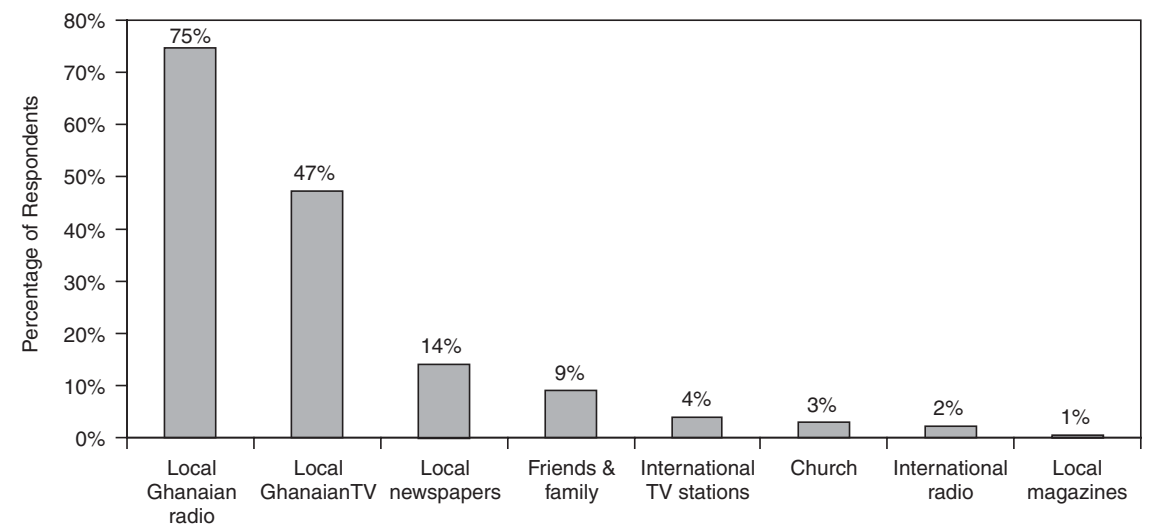


receive their information from local radio. Therefore, local radio was the media channel on which the communication strategy was most focused. Further desegregation shows that in urban Accra, for example, three FM radio stations together control about 80 percent of the market.

A further example comes from Kenya. In reviewing information related to how people receive information, the polls indicate that overall 67 percent of people in the country receive information from radio, specifically the Swahili service of the Kenya Broadcasting Corporation. A further break down of the numbers, however, finds that in urban Nairobi only 10 percent of people receive their information from this source and about 36 percent receive their information from a Nairobi-based English language FM station. In designing a communication strategy in Kenya, the CBA would advise use of different channels to reach people, depending on where they lived. This research helps to target information specifically to the identified audiences.

The development of the messages that will be used in the communication campaign is also critical to the communication campaign. Messages can be tested with various audiences (as the chart following illustrates). This message testing also forms part of the strategic decisionmaking that comes from the CBA.

During the course of a communication campaign it may be necessary to change the message or the position. During the Ghana water reform program, for example, opposition to the program was very intense over the decision to bring in a management consultant. The opposition to the project continued to paint it as a "privatization" program when in fact nothing was being sold and all assets would remain with the government. The private public partnership was only about a management contract. Since this was a difficult concept to explain, the decision was made to shift the nature of the debate away from the process to the expected outcomes of the project. This change in message altered the dynamics of the debate, developing more support for the project. Figure 13 summarizes the main messages tested for the water sector reform in Ghana.

\section{Capacity-building for Achieving Effective Communication}

To improve the impact of communication interventions, it is crucial to design training components to help operational staff, governments, and their communication staff develop and implement strategic communication activities. Training may be needed in communication and media skills, research and analysis, and strategy development. Indeed, capacity-building is a crucial activity because governments and implementing agencies are responsible for delivering all of the technical components of the project, of which communication constitutes one of the most difficult and vulnerable aspects.

Capacity-building is extremely important at the grassroots level, where the communication mechanisms need to facilitate and guarantee the inclusion and participation of relevant stakeholders in the decisionmaking process. The challenge of establishing and managing such a mechanism lies first and foremost in the governments' lack of understanding about the use of effective communication tools in the successful delivery of the project. This is compounded by the absence or low capacity of the implementing agencies to carry out sound communication activities. 
Figure 13. Messages

Of all the messages, respondents agreed the most that the Ghanaian government should be responsible for ensuring the poor have access to water.

\begin{tabular}{|c|c|c|c|c|}
\hline Issue & $\begin{array}{l}\text { Strongly } \\
\text { Disagree }\end{array}$ & $\begin{array}{l}\text { Somewhat } \\
\text { Disagree }\end{array}$ & $\begin{array}{l}\text { Somewhat } \\
\text { Agree }\end{array}$ & $\begin{array}{l}\text { Strongly } \\
\text { Agree }\end{array}$ \\
\hline $\begin{array}{l}\text { Even if there is private sector participation in water service and } \\
\text { delivery, I think that the Ghanaian government should be ultimately } \\
\text { responsible for ensuring that the poorest people in Ghana have access } \\
\text { to clean water. }\end{array}$ & $2 \%$ & $5 \%$ & $20 \%$ & $74 \%$ \\
\hline $\begin{array}{l}\text { If private sector gets involved with operating and managing water } \\
\text { service, the price will increase, but so will quality and service. }\end{array}$ & $7 \%$ & $9 \%$ & $34 \%$ & $50 \%$ \\
\hline $\begin{array}{l}\text { If they want to improve the water system, it would be best to fix what is } \\
\text { wrong with Ghana Water Company rather than bringing in PSP. }\end{array}$ & $9 \%$ & $14 \%$ & $31 \%$ & $46 \%$ \\
\hline $\begin{array}{l}\text { Ghanaians do not mind who is in charge of the water service delivery, } \\
\text { so long as there is an affordable, dependable source of clean water. }\end{array}$ & $18 \%$ & $14 \%$ & $25 \%$ & $43 \%$ \\
\hline International private sector participation is good for Ghana. & $9 \%$ & $13 \%$ & $37 \%$ & $41 \%$ \\
\hline $\begin{array}{l}\text { If there were private sector participation in water service and delivery, } \\
\text { then I believe the private sector should be ultimately responsible for } \\
\text { ensuring that the poorest people in Ghana have access to clean water. }\end{array}$ & $16 \%$ & $23 \%$ & $27 \%$ & $35 \%$ \\
\hline $\begin{array}{l}\text { The poorest people in Ghana will not be well served by private sector } \\
\text { participation in water service delivery. }\end{array}$ & $23 \%$ & $24 \%$ & $25 \%$ & $28 \%$ \\
\hline $\begin{array}{l}\text { If private sector gets involved with operating and managing water } \\
\text { service, the price will increase, but quality and service will not. }\end{array}$ & $24 \%$ & $23 \%$ & $27 \%$ & $26 \%$ \\
\hline
\end{tabular}

In the case of the property rights projects, for example, legal and technical staff who have constant interactions with the project beneficiaries - the majority of whom belong to the indigenous or minority groups-should be trained in improving their communication skills to achieve better results. This training would require extra effort to translate technical topics into a simpler, easier-to-understand language that is also socially and culturally sensitive for the target stakeholder groups.

The CBA identifies the current capacities of all the relevant implementers and develops a skills needs assessment along with the required training programs. Figure 14 presents one of the aspects covered in capacity building activities (training or technical assistance) to prepare the communication strategy for a private-public partnership in a water and sanitation project. The main areas of intervention were prioritized and the main audiences identified. Based on this analysis, the project implementation unit in the country identifies the objectives for each audience, the main activities to reach the objectives and the capacity needed to implement the activities.

\section{Ensuring Internal Coordination and Consistency}

The CBA identifies the appropriate internal communication mechanisms that facilitate the implementation of internal reforms in the institution and helps to properly engage the employers. An appraisal of the extent of internal consensus within government on the reform, policy, or project is fundamental to designing a development initiative. It is also critical for starting a genuine process of ownership with the inclusion of different stakeholders, especially the internal actors. 


\section{Figure 14. Guidelines}

- The main areas of intervention are: (i) Public Information \& Education;

(ii) Advocacy for consensus; (iii) Internal Communication; and

(iv) Participation (CSO $=>$ social accountability)

- Identify the main objectives for the Communication Strategy based on the identification of the key audiences and objectives. As example:

\begin{tabular}{|c|l|l|l|}
\hline Audience & \multicolumn{1}{|c|}{ Objective } & \multicolumn{1}{|c|}{ Activity } & \multicolumn{1}{c|}{ Capacity needed } \\
\hline \multirow{4}{*}{ Media } & $\begin{array}{l}\text { Provide timely, proactively and } \\
\text { adequate information } \\
\text { regarding the PPP process }\end{array}$ & $\begin{array}{l}\text { Identify International } \\
\text { successful cases on } \\
\text { PPP that might resonate } \\
\text { in the city }\end{array}$ & $\begin{array}{l}\text { Staff for research and } \\
\text { develop the stories } \\
\text { (articles will be planned } \\
\text { and sent) }\end{array}$ \\
\cline { 2 - 5 } & $\begin{array}{l}\text { Prove that PPP is the most } \\
\text { suitable and best alternative } \\
\text { for the city }\end{array}$ & $\begin{array}{l}\text { Identify testimonies of } \\
\text { consumers that support } \\
\text { the PPP alternative }\end{array}$ & $\begin{array}{l}\text { Staff for research and } \\
\text { develop the stories. }\end{array}$ \\
\cline { 2 - 4 } & $\begin{array}{l}\text { Strengthen the networking } \\
\text { with the media }\end{array}$ & $\begin{array}{l}\text { Invite journalist to study } \\
\text { tours in specific } \\
\text { locations }\end{array}$ & $\begin{array}{l}\text { Staff to update the media } \\
\text { list and develop } \\
\text { relationship with them }\end{array}$ \\
\cline { 2 - 4 } & $\begin{array}{l}\text { World Water Day: Work } \\
\text { breakfast with key } \\
\text { journalists to discuss the } \\
\text { vision of the water } \\
\text { sector }\end{array}$ & $\begin{array}{l}\text { Staff to update the media } \\
\text { list and develop } \\
\text { relationship with them }\end{array}$ \\
\hline
\end{tabular}

By integrating communication mechanisms into the design of development initiatives, an effective flow of information among all relevant stakeholders is achieved, facilitating coordination and accomplishing better levels of transparency and governance in the project. The CBA produces the basis for an effective inter-institutional communication plan.

Coordination mechanisms are critically important in achieving better alignment and consistency in the vision and messages that should be delivered by all the relevant internal stakeholders, particularly the implementing agencies within government. The internal consistency of the messages will be reflected in a sound and solid message to the external audiences that will build up the credibility, image, and reputation of the overall project and the implementing agencies.

\section{Conclusion}

The use of strategic communication tools and techniques helps citizens better understand their governments' visions in implementing reforms. Over the last few years, the strategic communication approach has played an increasingly important role in minimizing the political, cultural, and social risks inherent in the development process. Strategic communication entails the development of programs designed to influence the voluntary behavior of key stakeholder audiences to achieve development objectives. This approach is particularly critical in development programs, where increasing the level of awareness about a development issue does not automatically produce 
the necessary sustainable changes in the public perception or behavior for a successful reform or project.

It has been proven that knowledge alone cannot produce a behavior change (for example, in the use of water, payment for services, and increase in tariffs). Going beyond the transmission of information to achieve a change in practices and behavior requires a reality check between the priorities identified in the technical and economic analysis and the concerns that relate to non-technical and non-financial analysis. Often, reforms are viewed from the standpoint of the implementing agencies, and not from the point of view of the people whose lives are directly affected by the reform. Strategic communication techniques can inform and encourage policymakers to base their decisions on a clear understanding of beneficiaries' perspectives from the beginning of a development initiative. The CBA is the strategic tool that can improve significantly the outcomes of development initiatives. 



\section{References}

Cabanero-Verzosa, Cecilia, and Paul Mitchell. 2002. "Communicating Economic Reform.” Development Communications Division, The World Bank, Washington, D.C.

Kaufmann, Daniel, Aart Kraay, and Pablo Zoido-Lobaton. 1999. “Aggregating Governance Indicators." The World Bank, Washington, D.C.

Knack, Stephen, and Philip Keefer. 1997. "Does Social Capital have and Economic Payoff? A Cross Country Investigation.” The Quarterly Journal of Economics (November): 1253.

Operations Evaluation Department (OED). 2004. "Economies in Transition.” The World Bank, Washington, D.C.

Mefalopulos, Paolo. Forthcoming. The World Bank Sourcebook on Development Communication. Washington, D.C.: The World Bank.

Mozammel, Masud, and Barbara Zatlokal. 2002. "Strategic Communication in PRSP." The World Bank, Washington, D.C.

Perrett, Heli. n.d. "Using Communication Support in Projects: The World Bank's Experience," World Bank Staff Working Papers N ${ }^{\circ} 551$.

Rice, Ronald E., and Charles K. Atkin. 2001. Public Communication Campaigns. California: Sage Publications.

Stiglitz, Joseph. 1998. "Knowledge for Development Economic Science, Economic Policy, and Economic Advice." Annual World Bank Conference on Development Economics.

Windahl, Suen, Benno Signitzer, and Jean T. Olson. 1992. Using Communication Theory. An Introduction to Planner Communication. California: Sage Publications.

World Bank. 2002. World Development Report 2002: Building Institutions for Markets. Washington, D.C. 


\section{Eco-Audit \\ Environmental Benefits Statement}

The World Bank is committed to preserving Endangered Forests and natural resources. We print World Bank Working Papers and Country Studies on 100 percent postconsumer recycled paper, processed chlorine free. The World Bank has formally agreed to follow the recommended standards for paper usage set by Green Press Initiative-a nonprofit program supporting publishers in using fiber that is not sourced from Endangered Forests. For more information, visit www.greenpressinitiative.org.

In 2006, the printing of these books on recycled paper saved the following:

\begin{tabular}{|c|c|c|c|c|}
\hline Trees $^{\star}$ & Solid Waste & Water & Net Greenhouse Gases & Total Energy \\
\hline 203 & 9,544 & 73,944 & 17,498 & 141 mil. \\
\hline $\begin{array}{c}400^{4} \text { in heightand } \\
6-8 \text { 'indiameter }\end{array}$ & Pounds & Gallons & Pounds $\mathrm{Co}_{2}$ Equivalent & BTUs \\
\hline
\end{tabular}



Communication-Based Assessment for Bank Operations is part of the World Bank Working Paper series. These papers are published to communicate the results of the Bank's ongoing research and to stimulate public discussion.

This publication is the fifth in a series of Working Papers sponsored by the Development Communication Division (DevComm) of the World Bank's External Affairs VicePresidency. This series is designed to share innovations and lessons learned in the application of strategic communication in development projects. Together with other donors, NGOs, and private sector partners, DevComm seeks to mainstream the discipline of development communication in development practice.

All development is ultimately about change, and this requires communication interventions. Communication must be framed in an integral "two-way" process that involves stakeholders, accounts for their perspectives, and understands their socio-political context. This two-way process constitutes a new communication approach, providing a better understanding of the development context, tailoring development initiatives during design and implementation, and contributing to more sustainable results. This paper presents the methodology used by DevComm and its clients to improve development outcomes based on a Communication-based Assessment (CBA) approach.

World Bank Working Papers are available individually or on standing order. These are also available online through the World Bank e-Library (www.worldbank.org/elibrary).
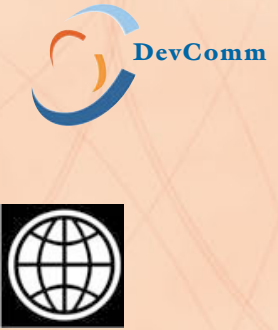

ISBN 978-0-8213-7165-7

THE WORLD BANK

1818 H Street, NW

Washington, DC 20433 USA

Telephone: 202 473-1000

Internet: www.worldbank.org

E-mail: feedback@worldbank.org

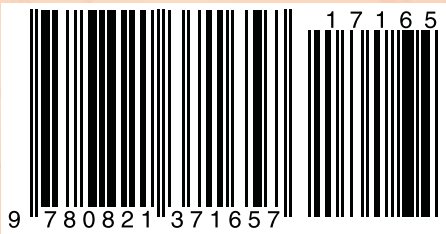

